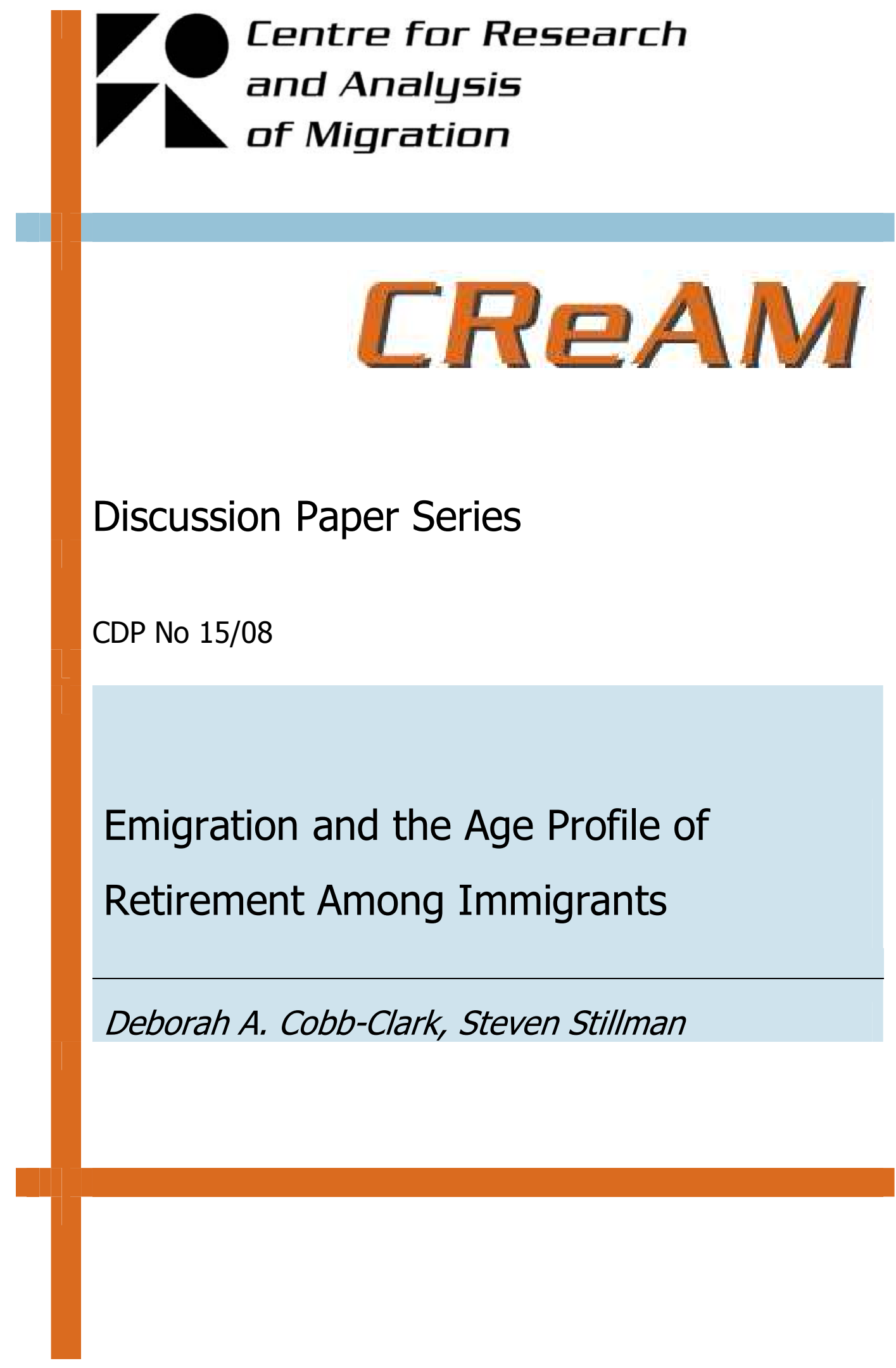




\title{
Emigration and the Age Profile of Retirement Among Immigrants
}

\author{
Deborah A. Cobb-Clark‡, Steven Stillman* \\ \# Economics Program and \\ Social Policy Evaluation, Analysis, and Research (SPEAR) \\ Centre Research School of Social Sciences, \\ Australian National University and \\ Institute for the Study of Labor (IZA), \\ *Motu Economic and Public Policy Research \\ Wellington, New Zealand and \\ Institute for the Study of Labor (IZA)
}

\section{Non-Technical Abstract}

This paper analyzes the relationship between immigrants' retirement status and the prevalence of return migration from the host country to their country of origin. We develop a simple theoretical model to illustrate that under reasonable conditions the probability of return migration is maximized at retirement. Reduced-form models of retirement status which control for the rate of return migration are then estimated using unique data on emigration rates matched to individual-level data for Australia. We find that immigrants, particularly immigrant women, are more likely to be retired than are native-born men and women with the same demographic, human capital, and family characteristics. Moreover, within the immigrant population, there is a negative relationship between the propensity to be retired and the return migration rate of one's fellow countrymen, particularly amongst men. This link is strongest for those individuals who are at (or near) retirement age and among those with the highest cost of return migration. These results suggest that the fiscal pressures associated with aging immigrant populations vary substantially across origin countries.

Keywords: retirement, immigrants, return migration, emigration, Australia

JEL Classification: J260, J010, J080 


\title{
Emigration and the Age Profile of Retirement Among Immigrants*
}

\author{
Deborah A. Cobb-Clark
}

\author{
Economics Program \\ and \\ Social Policy Evaluation, Analysis, and Research (SPEAR) Centre \\ Research School of Social Sciences, \\ Australian National University \\ and \\ Institute for the Study of Labor (IZA)
}

\section{Steven Stillman}

Motu Economic and Public Policy Research

Wellington, New Zealand

and

Institute for the Study of Labor (IZA)

\section{December 2008}

\begin{abstract}
:
This paper analyzes the relationship between immigrants' retirement status and the prevalence of return migration from the host country to their country of origin. We develop a simple theoretical model to illustrate that under reasonable conditions the probability of return migration is maximized at retirement. Reduced-form models of retirement status which control for the rate of return migration are then estimated using unique data on emigration rates matched to individual-level data for Australia. We find that immigrants, particularly immigrant women, are more likely to be retired than are native-born men and women with the same demographic, human capital, and family characteristics. Moreover, within the immigrant population, there is a negative relationship between the propensity to be retired and the return migration rate of one's fellow countrymen, particularly amongst men. This link is strongest for those individuals who are at (or near) retirement age and among those with the highest cost of return migration. These results suggest that the fiscal pressures associated with aging immigrant populations vary substantially across origin countries.
\end{abstract}

Keywords: retirement, immigrants, return migration, emigration, Australia JEL: J260, J010, J080

\footnotetext{
* This paper uses confidentialised unit record file data from the Household, Income and Labour Dynamics in Australia (HILDA) survey. The HILDA Project was initiated and is funded by the Department of Families, Housing, Community Services, and Indigenous Affairs (FaHCSIA) and is managed by the Melbourne Institute of Applied Economic and Social Research (MIAESR). The findings and views reported in this paper, however, are those of the authors and should not be attributed to FaHCSIA, MIAESR, or Motu. Corresponding Author: Deborah Cobb-Clark, Economics Program, Research School of Social Sciences, Australian National University, Canberra ACT, 0200 Australia. E-mail: Deborah.Cobb-Clark@anu.edu.au. Phone: 61-2-6125-3267 Fax: 61-26125-0189. Other Author Contact: Steven Stillman, stillman@motu.org.nz.
} 


\section{Introduction}

Over the past several decades, economists have made great strides in understanding the migration patterns, assimilation processes, and economic impact of the now nearly three percent of the world's population living outside their country of birth (see UN 2006). Most of our understanding comes from analyses of prime working-age immigrants who are assumed to remain permanently in their new country. Although return migration occurs frequently, we know very little about how host-country outcomes for temporary and permanent migrants differ. ${ }^{1}$ Moreover, we know almost nothing about the labor market behavior of older immigrant workers - despite an explosion of research analyzing retirement decisions more generally. These gaps are unfortunate because in many countries large numbers of immigrants are approaching retirement age. ${ }^{2}$ The fiscal pressures stemming from an aging immigrant population will depend on immigrants' retirement decisions and return migration patterns. In particular, host countries will experience lower costs associated with old-age pensions and health care if immigrants delay their retirement or choose to return home in their old age.

This paper fills a void in the literature by investigating the relationship between immigrants' retirement status and the prevalence of return migration from the host country to their country of origin. We begin by developing a simple theoretical model to illustrate that under reasonable conditions the probability of return migration is maximized at retirement. Despite a large, mainly theoretical, literature analyzing the return migration decision (see Dustmann and Weiss 2007 for a review), the effects of retirement on immigrants' incentives to return home have been completely overlooked. We use this framework to analyze the

\footnotetext{
${ }^{1}$ Estimates suggest, for example, that between 20 and 50 percent of legal immigrants to the United States emigrated to another country in the 1960s and 1970s (Jasso and Rosenzweig 1982; Warren and Peck 1980). See Dustmann and Weiss (2007) for a review of the evidence on the magnitude of return migration.

${ }^{2}$ For example, in Australia fully 14.6 percent of the foreign-born population is between the ages of 55-64 in comparison to 7.9 percent of the Australian-born population (authors' calculations based on ABS 2003), while the proportion of the native- and foreign-born populations between the ages of 55-64 is virtually identical in Germany (12.4 vs. 12.6 percent) and the U.S. (20.5 vs. 20.2 percent) (Bauer et al. in press; Schmidley 2001).
} 
retirement patterns of immigrants to Australia using data from the Household, Income and Labour Dynamics in Australia (HILDA) Survey. Australia is a particularly attractive country for studying the effects of return migration on the age profile of immigrant retirement because nearly one in four individuals in the Australian population is foreign-born (ABS 2007a) and, unlike the case in most countries, accurate data on return migration rates for individuals from different countries of birth are available. We are particularly interested in the following questions. First, how does the age profile of retirement differ for immigrants and the native-born? Second, what role do compositional differences in the characteristics of native- and foreign-born populations play in producing these differences? Finally, does the propensity for immigrants to be retired depend on the country-specific probability of return migration?

We find that immigrants, particularly immigrant women, are more likely to be retired than are native-born men and women with the same demographic, human capital, and family characteristics. Moreover, within the immigrant population, there is a negative relationship between the propensity to be retired and the return migration rate of one's fellow countrymen, particularly amongst men. This link is strongest for those individuals who are at (or near) retirement age and among those with the highest cost of return migration.

\section{The Previous Literature: Return Migration and Immigrant Retirement}

The economics literature on return migration has been primarily concerned with understanding the incidence and optimal timing of this decision (Hill 1987; Stark et al. 1997; Dustmann and Kirchkamp 2002; Dustmann 2003b). While immigration itself typically stems from superior economic opportunities in the host country, immigrants' return migration is assumed to be driven by preferences for (or lower costs of) consumption at home (Hill 1987; Djajić 1989; Dustmann 1997b; Stark et al. 1997) or concerns for one's children (Dustmann 
2003a). The potential for return migration has important consequences for immigrants' hostcountry decisions regarding work effort (Djajić 1989; Galor and Stark 1991), labor market participation (Dustmann 1997a), savings behavior (Galor and Stark 1990; Dustmann 1997b; Stark et al. 1997), and human capital investments (Dustmann 1999, 2007). Immigrants who anticipate returning home to relatively unfavorable economic conditions are expected to have higher participation rates and to work harder than either permanent immigrants or the nativeborn, for example (Galor and Stark 1991; Dustmann et al. 1997a). Temporary migration may also reduce the incentives for human capital investment (Dustmann 1999, 2007), but increase the incentives for remittances (Merkle and Zimmermann 1992). Finally, the effect of remigration on savings behavior depends on the wage differential and relative risk in the host and home countries (Dustmann 1997b). ${ }^{3}$

Difficulties in measuring return migration have limited empirical analyses of this process. As Dustmann and Weiss (2007) note, "there are typically no procedures in place that register immigrants who leave a country". At the macro level, this leaves researchers attempting to combine information from various censuses and surveys to infer the numbers (and characteristics) of immigrants who appear to have emigrated (e.g. Dustmann and Weiss 2007). At the micro level, researchers often rely on immigrants' stated intensions regarding return migration to understand how the behavior of temporary and permanent migrants differs. The general conclusion is that immigrants who intend to emigrate both save and remit more than immigrants who intend to remain permanently in the host country (Merkle and Zimmermann 1992; Sinning 2007; Bauer and Sinning in press).

Previous researchers have not studied the link between immigrants' intentions to emigrate and the timing of their retirement - though it seems reasonable to expect one. Moreover, given the importance of wage differentials in economic models of the migration

\footnotetext{
${ }^{3}$ Borjas and Bratsberg (1996) conclude that return migration intensifies the selection associated with the initial immigration process.
} 
decision, it is surprising that theoretical models do not account for the effect of retirement on the incentives for return migration. ${ }^{4}$ The empirical evidence certainly suggests that many immigrants anticipate either returning to their home country or moving frequently between the home and host countries after retirement (De Coulon and Wolff, 2006). ${ }^{5}$ In what follows, we illustrate the theoretical effect of retirement in raising the incentives for immigrants to leave the host country and return home. We subsequently assess the effect that the level of return migration has on the age profile of retirement in the immigrant population.

\section{Theoretical Framework: The Effect of Retirement on Return Migration}

We begin by developing a simple model of the net benefit of return migration concentrating on immigrants' decisions about where (rather than how much) to work. ${ }^{6}$ Immigrants decide whether or not to return to their country of origin on the basis of the total future consumption achievable in the two countries until the end of life. The model is static and we do not account for either uncertainty in — or the trajectory of — wages, prices, or consumption over time. This simple approach allows us to abstract from unnecessary complexity. Extensions of this basic framework are considered briefly below.

Our main interest is in understanding how retirement affects the incentives for return migration. An individual's retirement date is assumed to be determined outside the model perhaps as a result of institutional arrangements that define the age at which he or she may access either public or employer-provided pension benefits. Consequently, immigrants save throughout their working lives to fund consumption in retirement. We assume that retirement savings may be only partially portable and that transferring them to the origin country may involve a loss of benefits. Finally, we assume that immigrants' preferred bundle of

\footnotetext{
${ }^{4}$ The exception is Dustmann and Kirchkamp (2002) who model the employment status of return migrants in the home country.

${ }^{5}$ This potential for return migration may provide a partial explanation for nativity differences in retirement expectations (Cobb-Clark and Stillman in press).

${ }^{6}$ See Hill (1987) who adopts a similar approach.
} 
consumption goods is constant across countries, but that it is less costly in the origin than in the host country (see Stark et al. 1997; Dustmann and Kirchkamp 2002).

Time is continuous in the model. Immigrants begin their lives in at $t=0$ in the host country and die at $t=1$. Retirement occurs at time $R$ with $0<R<1$. Consider first the savings process. In the period prior to retirement, immigrants save a portion of their earnings to fund post-retirement consumption. Accumulated retirement savings at time $t$ are then given by:

$$
S_{t}=D\left[t\left(w^{H}-c^{H}\right)\right]+(1-D)\left[R\left(w^{H}-c^{H}\right)-(t-R) c^{H}\right]
$$

where $w^{H}$ denotes host-country wages, $c^{H}$ is the consumption level in the host country, and $D$ is a simple indicator variable which takes the value 1 in the pre-retirement period $(t<R)$ and 0 otherwise $(t \geq R)$. In the pre-retirement period $(D=1)$, savings are equal to total earnings minus total consumption to date. In the post-retirement period ( $D=0)$, savings equal the total savings accumulated at retirement minus any post-retirement consumption. Consumption levels are chosen so as to exhaust any savings at the end of life.

Following others in the literature (e.g. Dustmann 1997a, 2007; Dustmann and Kichkamp 2002), we assume that at an exogenous time $t=t^{*}$ immigrants make a decision whether or not to leave the host country and return home. Immigrants benefit from return migration if their accumulated retirement savings and future earnings afford a higher standard of living in the origin country than in the host country. Specifically, the net benefit to return migration at time $t^{*}$ is given by the difference in future total consumption achievable in the two countries. Given that we assume that there are no bequests and all resources are exhausted at death, this implies that future consumption over ones remaining life time is equivalent to future resources. Immigrants are assumed to emigrate whenever the net benefits from doing so are positive. Return migration occurs, therefore, if and only if 


$$
N B_{t^{*}}=R_{t^{*}}^{O}-R_{t^{*}}^{H}>0
$$

where $R_{t^{*}}^{O}$ and $R_{t^{*}}^{H}$ are the future resources available at time $t^{*}$ if immigrants do and do not choose to return migrate, respectively. More specifically, the net benefit to return migration at time $t^{*}$ can be written in terms of accumulated savings and any future earnings over ones remaining career as follows

$$
N B_{t^{*}}=\frac{1}{p}\left\{S_{t^{*}}+\left(R-t^{*}\right) w^{O} D-\bar{C}\right\}-\left\{S_{t^{*}}+\left(R-t^{*}\right) w^{H} D\right\}
$$

where $w^{O}$ captures origin-country wages, $\bar{C}$ represents a fixed cost (e.g. the loss of pension benefits, travel costs, etc.) associated with return migration. ${ }^{7}$ The host-country price level is normalized to 1 and relative origin-country prices are given by $p$. We assume $w^{O}<w^{H}$ and $p<1$ implying that although economic opportunities are better in the host country than in the origin country, immigrants' preferred consumption bundle is less expensive at home.

The net benefit to return migration will be positive at time $t^{*}$ if the resources available for consumption over an immigrant's remaining life time are higher in the origin country than in the host country. The last term in equation (2) reflects the total resources available if an immigrant decides to remain in the host country. Total resources include retirement savings accumulated to time $t^{*}$ while working in the host country as well as an immigrant's earnings over his or her remaining working life in the host country. Post-return resources levels are given by the first term on the right-hand side of equation (2). Although accumulated savings are the same $\left(S_{t^{*}}\right)$, future resources will be lower in the origin country because $w^{O}<w^{H}$ and because return migrants must also pay the fixed costs associated with return migration $(\bar{C})$.

\footnotetext{
${ }^{7}$ We ignore the effects of time discounting for simplicity
} 
At the same time, each dollar of resources funds more consumption in the origin country because prices $(p)$ are lower. Consistent with other models in the literature (Djajic 1989; Dustmann 1997b; Stark et al. 1997), remigration may occur despite persistently higher hostcountry wages because consumption is less expensive in the origin country.

How does retirement affect the probability of return migration? To address this question, we consider the way in which the incentives for return migration change over time both before and after retirement. In the post-retirement period $\left(t^{*} \geq R\right)$, immigrants choose to return to their country of origin if and only if

$$
M_{t^{*}}=I\left(\frac{(1-p) S_{i^{*}}-\bar{C}}{p}>0\right)
$$

where $I$ denotes a simple indicator function and $M$ reflects the return migration decision. Substituting accumulated savings as given by equation (1) and rearranging implies that

$$
\begin{aligned}
M_{t^{*}} & =I\left((1-p) S_{t^{*}}>\bar{C}\right) \\
& =I\left((1-p)\left[S_{R}-\left(t^{*}-R\right) c^{H}\right]>\bar{C}\right)
\end{aligned}
$$

Consequently, after retirement, return migration occurs if the costs of return migration $(\bar{C})$ — principally the loss of retirement savings — are less than the additional consumption made possible by consuming ones remaining savings in the origin country where prices are lower. Equation (5) implies that the change in the probability of return migration over time in the post-retirement period is given by:

$$
\frac{\partial \operatorname{Pr}(M=1)}{\partial t^{*}}=-(1-p) c^{H}
$$

Before retirement (i.e. in periods $t^{\prime}<R$ ), however, immigrants also take into account the effect that return migration will have on their future earnings. Given the net benefit to 
return migration shown in equation (3), immigrants choose to return migrate in the preretirement period if and only if

$$
M_{t^{\prime}}=I\left(\frac{S_{t^{\prime}}+\left(R-t^{\prime}\right) w^{O}-\bar{C}-p\left[S_{t^{\prime}}+\left(R-t^{\prime}\right) w^{H}\right]}{p}>0\right)
$$

Substituting accumulated savings and rewriting implies that immigrants choose to return migrate in the pre-retirement period whenever:

$$
\begin{aligned}
M_{i}= & I\left(S_{t}+\left(R-t^{\prime}\right) w^{O}-p S_{i}+p\left(R-t^{\prime}\right) w^{H}>\bar{C}\right) \\
& =I\left((1-p) S_{i}-\left(R-t^{\prime}\right)\left(p w^{H}-w^{O}\right)>\bar{C}\right) \\
& =I\left((1-p) t^{\prime}\left(w^{H}-c^{H}\right)-\left(R-t^{\prime}\right)\left(p w^{H}-w^{O}\right)>\bar{C}\right)
\end{aligned}
$$

Immigrants return migrate before retirement only if the advantages of consuming ones accumulated savings in the origin country outweigh both the cost of return migration and the earnings loss associated with returning to a low-wage labor market. Consequently, the change in the probability of return migration over the pre-retirement period is given by:

$$
\frac{\partial \operatorname{Pr}(M=1)}{\partial t}=\left(w^{H}-w^{O}\right)-(1-p) c^{H}
$$

There are several things to note about these changes over time. First, the probability of remigration declines over the post-retirement period so long as consumption in the origin country is less expensive than in the host country (i.e. $p<1$ ) (see equation (6)). Every year that return migration is delayed involves a loss associated with consuming in the higher price market which is no longer being compensated by the higher wages in the host country. In the pre-retirement period, the probability of return migration increases every year so long as the 
wage advantage afforded by the host country dominates the higher living costs. This will be true whenever there is a positive economic return to immigration to the host country in the first place. Together these relationships imply that the probability of return migration is maximized at the point of retirement when the wage advantage of the host country relative to the origin country is no longer relevant and the consumption benefits of moving ones retirement savings to the lower cost country are maximized (see Figure 1).

Economic models of the immigration process typically rest upon the superior labor market opportunities in the host country. Models of return migration, on the other hand, often rely upon lower costs of (or preferences for) consumption in the home country as the driving force behind the decision to leave the host country despite higher host-country wages (Djajić 1989; Dustmann 1997b; Stark et al. 1997). In this context, our simple model is useful in highlighting the changes in the incentives for return migration that occur at retirement when higher relative wages are no longer a factor in immigrants' decisions about whether to stay or to return home.

\section{The Data}

\subsection{The Household Income and Labour Dynamics Survey}

The main data source used for the analyses in this paper is the Household Income and Labour Dynamics in Australia (HILDA) Survey which collects longitudinal information from a nationally-representative sample of more than 7,600 Australian households encompassing almost 20,000 individuals aged 15 and older (see Wooden, et al. 2002). As fully 22.1 percent of the Australian population is foreign-born (ABS 2007), the HILDA sample includes a large number of immigrants from a diversity of origin countries (eighty-eight, in fact). Moreover, while many studies of retirement behavior are based only on samples of older individuals, each non-employed HILDA respondent aged 45 and over is asked about his or her retirement 
status. $^{8}$ The ability to measure retirement status among several cohorts of native- and foreign-born workers makes HILDA data well suited to estimating nativity differences in the age profile of retirement.

We pool the first five waves of HILDA data covering the years 2001 to 2005 to examine the retirement status of native- and foreign-born men and women over the age of 45 . We have made a number of necessary sample restrictions. Specifically, individuals under the age of 45 were not asked the retirement questions and have been dropped from the sample. This results in a sample of 7,728 individuals aged 45 and over. We then drop a total of 457 individuals who either 1) have never worked (218 individuals), 2) are Aboriginal or Torres Strait Islanders (92 individuals) or 3) are missing information for retirement status or other key variables of interest (88 individuals). This leaves us with our main estimation sample of 7,271 individuals, 5,117 of whom are native-born and 2,154 of whom are foreign-born. Each individual provides, on average, 3.8 waves of data, leading to 27,408 observations in our estimation sample. Because retirement patterns are likely to depend on a number of factors which differ by region of origin, in much of our analysis we differentiate between immigrants from English-speaking (ESB) and non-English-speaking (NESB) background countries. ${ }^{9}$ Details about individual characteristics by gender and immigrant status are shown in Appendix Table 1.

\subsection{The Timing of Retirement among Immigrants and Natives}

We begin by examining the declared retirement status of the individuals in our sample (see Table 1). The results indicate that immigrant women and immigrant men from non-Englishspeaking backgrounds are more likely to report being retired when asked directly about their retirement status. Overall, 39 per cent of Australian-born men and 40 percent of foreign-born

\footnotetext{
${ }^{8}$ In particular, all non-employed respondents were asked "Have you retired (completely) from the workforce." Response categories include: yes, no, and never worked.

9 The English-speaking background countries are the United Kingdom, Ireland, United States, Canada, New Zealand and South Africa.
} 
men from English-speaking countries say that they have retired from the labor market. In contrast, fully 45 percent of immigrant men from non-English-speaking backgrounds report being retired. Retirement rates are also approximately five percentage points higher among immigrant women than among Australian-born women.

\section{Table 1 Here}

These aggregate retirement rates mask important variation in the timing of retirement across groups. The incidence of retirement by age is shown in Figure 1. In the absence of cohort effects on retirement, these figures can be interpreted as the cumulative distribution of retirement at different ages. The relationship between region of origin and the retirement profile of immigrant men is particularly striking for men under the age of 60 . Retirement rates are much higher among male immigrants from non-English-speaking backgrounds than among immigrant men with English-speaking backgrounds. By age 60, fully 44 percent of non-English-speaking background men say that they are retired in comparison to 30 percent of English-speaking background men. In comparison, approximately 37 percent of Australian-born men have retired by age 60 . After age 60 , there is a sharp increase in the retirement rates of immigrant men from English-speaking countries so that by age 65 the cumulative retirement rate of immigrant men (approximately 80 percent) is largely independent of language background and is substantially higher than that of Australian-born men (62 percent). The gap in the retirement rates of foreign- and native-born men does not completely close until after age 70 .

\section{Figure 1 Here}

Not surprisingly, retirement occurs much earlier for women and at any given age a higher proportion of women than men report being retired. Before the age of 55, however, the relative retirement rates of women mirror those of men with English-speakingbackground immigrant women being less and non-English-speaking-background immigrant 
women being more likely to be retired than their native-born counterparts. There is a rapid increase in retirement of immigrant women after age 55 so that by age 60 there are large disparities in retirement rates across groups. While approximately 46 per cent of Australianborn women are retired by age 60 , this is true of 73 percent of immigrant women from nonEnglish-speaking backgrounds and 58 percent of women from English-speaking backgrounds. This disparity is largely eliminated by age 65 , however.

Taken together, these results suggest that there are substantial differences in the timing of retirement among the native-born, English-speaking-background immigrants and non-English-speaking-background immigrants. Immigrants from non-English-speaking backgrounds appear to retire earlier than other groups although by age 65 much of the gap has closed. Thus, the story is one of early retirement. The exception is that Australian-born men appear to be much more likely than foreign-born men to work past the age of 65 .

\subsection{The Probability of Return Migration}

Although most countries do not systematically collect information on emigrants (see Dustmann and Weiss 2007), Australia is an exception. Australia's status as an island nation implies that all individuals entering or leaving the country do so through one of only seven international airports. Moreover, each person entering or leaving Australia is required to provide the Australian Department of Immigration and Citizenship (DIAC) with a completed Incoming or Outgoing Passenger declaration at the airport. These cards are legal documents and there are penalties for not filling them out completely or for making false statements. The data obtained from these cards are then matched to the personal information obtained from an electronic swipe of the person's passport. ${ }^{10}$

\footnotetext{
${ }^{10}$ See http://wwww.immi.gov.au and http://www.infrastructure.gov.au for more information.
} 
We use the published statistics on permanent departures from these data in conjunction with census information to calculate a country-specific emigration rate for 1996 $-2001\left(R_{j}^{96-01}\right)$ for all 88 countries of births represented in HILDA as follows ${ }^{11}$ :

$$
R_{j}^{96-01}=\frac{E_{j}^{96-01}}{E_{j}^{96-01}+P_{j}^{01}}
$$

where $j$ indexes country of birth (including Australia), $E_{j}^{96-01}$ is the total number of individuals born in country $j$ who permanently left Australia between 1996 and 2001 and $P_{j}^{01}$ is the number of individuals enumerated in the 2001 Australia census who were born in country $j$. This emigration rate for each country $j$ is then matched to all individuals in our estimation sample who were born in that country. The denominator of the ratio in equation (10) reflects the population of individuals from country $j$ who would have resided in Australia in 2001 in the absence of emigration.

Information about both the weighted (by sample size) and unweighted densities of emigration rates are provided in Figure 2. The emigration rate of immigrants to Australia ranges from 0.005 (Italy) to 0.090 (Hong Kong). ${ }^{12}$ Immigrants from China, New Zealand, and Hong Kong have relatively high return migration rates, while immigrants from countries such as Italy, India and Germany are more like to remain in Australia. Emigration rates are plotted on a log-scale in each graph and, as can be seen in the unweighted results, the distribution across countries in approximately log-normal. We use a log-normal functional form for the emigration rate in all our descriptive results and regression analyses. In all cases this provides a better model fit than when we treat emigration rates as a linear variable.

\section{Figure 2 Here}

\footnotetext{
${ }^{11}$ Specifically, permanent departures capture the number of those departing who report that they are leaving Australia permanently. See Department of Immigration and Citizenship (2007) for emigration statistics and ABS (undated) for population statistics.

${ }^{12}$ Taiwan has the highest emigration rate in our sample at 0.097 , but there are only 9 immigrants from Taiwan in HILDA as opposed to 51 from Hong Kong, thus we focus on Hong Kong when making comparisons.
} 
Our theoretical model predicts that as the net benefits of return migration increase, the proportion of the immigrant population that chooses to remain in Australia after retirement falls. Consequently, we expect immigrants from countries with high return migration rates to be on average younger and less likely to be retired. We investigate this issue by plotting country-specific retirement rates for those aged 45 plus from HILDA and the proportion of the population aged 65 and older from each country of birth, as measured in the 2006 Census (ABS 2007b), against emigration rates (see Figures 3 and 4). The size of the plot circles in Figure 3 are proportional to the HILDA sample size for men/women in each country and the solid line in each graph is the best linear fit of the data, with each point weighted by the HILDA sample size for men/women in each country. The plot circles and solid line are similarly defined in Figure 4, except the total female/male population in Australia from each country of birth are instead used as weights.

\section{Figures 3 and 4 Here}

These figures indicate that, as predicted by our theoretical model there is a large, negative, and significant relationship between a country's return migration rate and the fraction of the immigrant population in Australia that is retired or over age 65. For example, only 12.2 percent of men and 35.3 percent of women from New Zealand aged 45 plus are retired compared to 58.2 percent of men and 71.2 percent of women from Italy. Likewise, less than 10 percent of the New Zealand-born population in Australia is aged 65 plus, while over 50 percent of the Italian-born population in Australia is in this age-group.

\section{Return Migration and Retirement Status}

\subsection{Estimation Model}

To explore the link between return migration and the pattern of retirement in more depth, we estimate reduced-form models of retirement status controlling for individuals' demographic 
and human capital characteristics. This allows us to assess the role that differences in the composition of the immigrant and native-born populations play in explaining differences in retirement status across these groups. Our objective is not to estimate a behavioral model of the retirement decision, but rather to understand the way the propensity to be retired at a point in time (i.e. retirement status) differs among subpopulations with different characteristics. Consequently, we adopt a cross-sectional estimator, pooling across HILDA waves to improve efficiency. ${ }^{13}$

We include in this regression model the emigration rate for the county of birth of each immigrant over the previous five year period (see equation (10)). These emigration rates capture the cross-national variation in institutional arrangements, price levels, etc. that underlie the aggregate costs and benefits of emigration for individuals from each specific origin country. Since the incentives for return migration are highest at retirement (see Section 3), we expect to observe fewer individuals remaining in Australia after retirement when the benefits of return migration are higher (alternatively costs are lower). In the limit, when return migration to country $j$ is nearly universal, none of the immigrants from country $j$ remaining in Australia would be retired. Thus, our theoretical model implies that we should find a negative relationship between country-of-origin-specific emigration rates and the propensity for an individual to report being retired.

We assume that an individual's propensity to be retired $\left(R_{i}^{*}\right)$ can be expressed as:

$$
R_{i j}^{*}=X_{i j} \beta+Z_{j} \phi+\varepsilon_{i j}
$$

\footnotetext{
${ }^{13}$ Estimating a joint behavioural model of retirement and return migration decisions is also of great interest. However, this would require panel data which both includes information about labour force status and follows individuals who emigrate. Such data does not currently exist.
} 
where $i$ indexes individuals, $X_{i j}$ captures demographic and human capital characteristics, $Z_{j}$ is the return migration rate, and $\varepsilon_{i j}$ is a random error term. The propensity to be retired is unobserved, so we create an indicator variable reflecting retirement status. Specifically,

$$
\operatorname{Pr}\left(D_{i j}=1\right)=\operatorname{Pr}\left(X_{i j} \beta+Z_{j} \phi+\varepsilon_{i j}>0\right)=\Phi(Q \gamma)
$$

where $Q=\left(X_{i j}, Z_{j}\right), \gamma=(\beta, \phi)$, and $\Phi$ is the standard normal cumulative density function. Finally, we assume that $\varepsilon_{i j} \sim N(0,1)$, is independent of the explanatory variables in equation (11) and is potentially clustered for individuals from the same country of birth, $j .{ }^{14}$

\subsection{The Determinants of Retirement Status}

We begin by examining the determinants of declared retirement status for men and women aged 45 and older. We consider three alternative specifications. The first controls only for nativity status, year, region and remoteness, while the second adds controls for individuals' demographic (a quadratic in age, marital status), human capital (education, a quadratic in labor market experience, health status) and household (number of children/adults) characteristics. ${ }^{15}$ The final specification also controls for return migration rates. ${ }^{16}$ Estimation

\footnotetext{
${ }^{14}$ Note that this also accounts for clustering over time in the error-term for a particular individual. As discussed in Moulton (1990), statistical inference can be seriously misleading when a regressor is measured at a more aggregated level than the observations in a regression, unless the regression allows for clustering at this more aggregated level.

${ }^{15}$ Specifications are as follows. Model 1: indicator variables for being born in an English speaking country other than Australia; being born in a non-English speaking country; waves 2-5, New South Wales (other than Sydney, default), the Australian Capital Territory, Melbourne, balance of Victoria, Tasmainia, Brisbane, balance of Queensland, Southern Australia, and Western Australia and Northern Territory; inner regional area, and outer regional/remote area (omitted category major city). Model 2 also includes: quadratic in age; quadratic in years of work experience; indicator variables for finishing year 12, having a vocational certificate, having a tertiary degree; and being currently married (or cohabitating) as well as the length of this relationship; the number of individuals aged 0-15, 16-20 and 21 plus in the household; and indicators for good, average, fair/poor, or missing self-reported health status. Model 3 also includes the log of the return migration rate (see equation (10)). Appendix table 1 reports summary statistics for all of the variables included in this analysis separately by gender and nativity status.
} 
results (marginal effects and standard errors) are reported separately by gender in Table $2 .^{17}$ Alternative results from a model of non-employment (rather than declared retirement) are substantially the same and are reported in Appendix Table 2.

The results indicate that, when we do not control for differences in individual and household characteristics, immigrant men from non-English-speaking background countries are 8.6 percentage points more likely to report being retired than are native-born men, while men from English-speaking background countries have retirement rates that are equivalent to native-born Australians. Immigrant women, irrespective of language background, are also somewhat more likely to report being retired than are native-born women, though the magnitude of the effect (between 4 and 5 percentage points) is smaller than that for men and is not significant at the 10 percent level.

\section{Table 2 Here}

The relationship between nativity and retirement status falls by more than half for men once we control for differences in men's age, education, experience, health, etc. Thus, nativity differences in men's retirement status are largely (though not completely) the result of compositional differences in the characteristics of native- and foreign-born populations. In contrast, the nativity gap in women's retirement status is magnified once we control for their characteristics. Immigrant women from English-speaking backgrounds are fully 9.0 percentage points more likely to be retired than otherwise similar native-born women, while non-English-speaking background women are 8.4 percentage points more likely to be retired.

\footnotetext{
${ }^{16}$ In order to continue to include the Australia-born in this specification, we assign the emigration rate for Australian-born Australians of 0.6 percent to these individuals. Because indicator variables are included for being foreign-born, this has no impact on our estimates of the relationship between return migration rates and the likelihood of being retired, but instead affects the interpretation of the immigrant background indicator variables. As discussed below, we focus our discussion on country-specific predicted probabilities instead of these coefficients thus eliminating this interpretation problem.

${ }^{17}$ All estimation is performed in STATA 10. Standard errors are calculated using the delta method accounting for clustering on country of birth. This also controls for clustering of individuals across time.
} 
Given the wide range of characteristics (in particular, age and health) accounted for in the model, these large differences in the retirement status of immigrant and native-born women are striking. At the same time, analyses of immigrant women's labor supply more broadly often conclude that the labor market assimilation profile that is typically observed for immigrant men does not easily generalize to immigrant women (e.g. Schoeni 1998; Blau et al. 2008). Researchers have argued that immigrant women's labor supply decisions are perhaps best understood as investments in their partners' labor market assimilation (e.g. Baker and Benjamin, 1997; Cobb-Clark and Crossley 2004) or in the context of gender roles (rather than work orientation) (Blau et al. 2008). These perspectives are also likely to be useful in understanding immigrant women's retirement decisions.

Both men and women are more likely to be retired if they are older or have fewer labor market opportunities (i.e. less work experience, lower education, and poorer health). ${ }^{18}$ Retirement status also appears to be linked to household composition. Retirement is substantially less common amongst those with teenage children at home, while retirement rates are also lower for those living in households with a relatively large number of other adults. Although newly married men are 10.6 percentage points less likely to be retired, the incidence of retirement increases significantly for each year the man has been in the relationship. After 30 years of marriage (the sample mean), married men have retirement rates that are statistically the same as single men. In contrast, newly married women are significantly more likely to be retired and this effect remains even after 30 years of marriage. These relationships between retirement status and individuals' other demographic, human capital, and household characteristics are unsurprising and are consistent with a growing literature analyzing the retirement decision (e.g. Lumsdaine and Mitchell 1999).

\footnotetext{
${ }^{18}$ Table 2 reports the total marginal effect implied by the coefficients on both the linear and squared age terms.
} 
Finally, consistent with our theoretical model, we find a negative relationship between the propensity to be retired and the return migration rate of one's fellow countrymen. Specifically, in the absence of return migration, immigrant men would be expected to have retirement rates between 9.0 (English speaking background) and 8.4 (non English speaking background) percentage points higher than native-born men, while immigrant women would have retirement rates that were between 13.2 (English speaking background) and 10.3 (non English speaking background) percentage points higher. ${ }^{19}$ The degree of return migration, however, is associated with a large fall in the propensity for immigrant men to be retired. The relationship between retirement status and return migration rates is also negative for women, though the effect is smaller and is not statistically significant.

\section{Table 3 Here}

To highlight the combined effect of English language background and return migration, we calculate predicted retirement rates holding individuals' characteristics constant at the overall sample mean (by gender) while varying immigrant status and return migration rates. In Table 3, we present the results for the five countries that each make up more than 4 percent of the foreign-born population in HILDA (in order of importance: UK; New Zealand; Italy; Germany; Netherlands) and three important Asian countries (China; Vietnam; and Hong Kong). Comparing the two extremes, we see that men (women) from Hong Kong, which has a return migration rate of 9.0 percent, are 21.6 (9.6) percentage points less likely to be retired compared to individuals from Italy, which has a return migration rate of 0.5 percent, holding everything else constant. This disparity implies that the nationalorigin mix of the immigrant inflow has important implications for the extent of return migration as well as the retirement status (and age structure) of the immigrant population.

\footnotetext{
${ }^{19}$ Note that the interpretation of the coefficients on the indicator variables for immigrant status differs across models. In particular, while in model 2 the effect of immigrant status is effectively evaluated at the mean return migration rate, in model 3 these same effects are evaluated at a return migration rate of 0 . In Table 3 , we calculate predicted retirement rates holding individuals' characteristics constant at the mean for the entire sample and varying immigrant status and return migration rates.
} 


\subsection{Retirement Status and Return Migration Rates: Variation Across Age-Groups}

All of the above results account for the effect of age on the propensity to be retired. Not surprisingly, we find that retirement rates are higher among older individuals. Still, this leaves open the possibility that the effects of return migration differ depending on the age of the individual. In particular, our theoretical model indicates that the link between retirement status and return migration should be the strongest for individuals who are closest to retirement age. We address this issue by re-estimating the three specifications described above for four separate age-groups. These age-groups are defined differently for men and women to take into account the fact that Australian women typically retire somewhat earlier than Australian men (see Cobb-Clark and Stillman in press). The predicted retirement rates (evaluated at the sample means by gender and age-group) implied by these estimates are reported separately by gender in Table 4, while selected marginal effects (and standard errors) are presented in Appendix Table $3 .^{20}$

\section{Table 4 Here}

We find no significant effect of return migration rates on the retirement status of men between the ages of 60 and 64 or for those aged 69 and older (see Appendix Table 3). Among relatively young men (aged 45 - 59), however, higher return migration rates are associated with a somewhat lower propensity to be retired. There is also a negative relationship between the propensity of men aged 65 to 69 to be retired and the return migration rate of their fellow countrymen. This effect is quite substantial. Specifically, while almost all men aged 65 to 69 from Italy (92.4 percent) or the Netherlands (87.8 percent) are predicted to be retired, this is true of only two-thirds (64.6 percent) of men from China and half (54.2 percent) of men from Hong Kong. These are dramatic differences given

\footnotetext{
${ }^{20}$ All models include the full set of controls as described above, however, we report only selected results in Appendix Table 3. Complete results are available upon request.
} 
that we are controlling for differences in the human capital and demographic characteristics of men from different origin countries.

Retirement status is linked to return migration rates only for women between the ages of 60 and 64. In this age group, however, the effect of return migration rates on retirement status is dramatic. Specifically, women in this age range from countries such as Italy and the Netherlands are almost 30 percentage points more likely to be retired than are otherwise similar women from countries such as New Zealand or Hong Kong for which return migration rates are higher.

It is striking that the effect of return migration rates on retirement status is most pronounced for the cohort of $65-69$ year old men and $60-64$ year old women. Although the institutional details of employer-provided pension plans can vary, Australian men (both citizens and permanent residents) qualify for the Age Pension provided by the Australian government at age 65 , while Australian women born before June 30,1944 qualify at age $63 .{ }^{21}$ Thus, taken together, our results strongly suggest that - consistent with our expectations - the link between retirement status and return migration is strongest for those individuals who are at (or near) retirement age.

\subsection{Retirement Status and Return Migration Rates: The Effect of Citizenship}

Our theoretical model demonstrates that the retirement status of immigrant populations can be directly linked to the costs and benefits of return migration. Groups that face a high cost (or low benefit) of return migration are expected to be disproportionately likely to remain in the host country after retirement. In the preceding analysis, we have used the return migration rate of one's fellow countrymen as a convenient proxy for the cross-national variation in the costs and benefits of return migration faced by different immigrant groups.

\footnotetext{
${ }^{21}$ See www.centrelink.gov.au.
} 
Here, we move on to examine whether - within immigrant populations - there is evidence that specific groups with higher costs of return migration are in fact disproportionately likely to remain in Australia (i.e. have higher average retirement rates).

We do this by re-estimating our model of retirement status classifying origin countries, not on the basis of their language background, but rather on the basis of whether or not they permit dual citizenship. This is then interacted with an indicator for whether or not the respondent has become a naturalized Australian citizen. ${ }^{22}$ Of the 70 origin countries available for this analysis, 40 allow dual citizenship. Among immigrants from the countries allowing dual citizenship 76.2 percent have become naturalised Australian citizens, while the corresponding rate for immigrants from countries that do not allow dual citizenship is 88.8 percent. We expect that immigrants who have become naturalized citizens despite coming from a country which does not allow dual citizenship will have higher costs of return migration and will be disproportionately likely to remain in Australia after retirement. On the other hand, immigrants who fail to become naturalized citizens even though they could do so without giving up their original citizenship may feel less attachment to Australia and may be more likely to return home at retirement. ${ }^{23}$

\section{Table 5 Here}

Table 5 presents the predicted retirement rates implied from this model estimated on both the samples of men and women and stratified by gender and age-group (see Appendix Table 4 for selected marginal effects). We find that among immigrants from countries that do

\footnotetext{
${ }^{22}$ Specifically, we drop our indicators for English-speaking- and non-English-speaking background from the model and instead add indicators for 1) naturalized Australian citizen from non-dual-citizenship country; 2) naturalized Australia citizen from dual-citizenship country; 3) not an Australian citizen from a non-dualcitizenship country; and 4) not an Australian citizen from a dual-citizenship country. The data on dual citizenship come from Brenchley (2000) and Renshon (2000). Data for 74 individuals from 18 countries were excluded from this analysis because information was not available on whether these countries allow dual citizenship. A further 546 individuals were dropped from this analysis because they attrited from HILDA prior to wave 5 when the citizenship data was first collected. Selected marginal effects (and standard errors) are presented in Appendix Table 4. Complete results are available upon request.

${ }^{23}$ The Australian government actively encourages immigrants to take up Australian citizenship. Immigrants entering Australia before July 1, 2007 are qualified to become Australian citizens after two years of permanent residence (www.immi.gov.au).
} 
not allow dual citizenship (for example, Germany, India, Vietnam and China) there is a great deal of disparity in the retirement rates of those who have and have not become naturalized citizens. Specifically, men who are naturalized Australians (and were required to give up their original citizenship) are 24.9 percentage points more likely to be retired than those who are not, while women who gave up their original citizenship to become Australian citizens are 13.3 percentage points more likely to be retired. The magnitude of this difference is striking given that we have controlled for differences in demographic (most notably age) and human capital characteristics.

We also find a positive effect of having Australian citizenship on the retirement rates of immigrants from countries that do allow dual citizenship status. This effect, however, is much smaller (less than two percentage points) and not statistically significant indicating that for immigrants from these countries the decision to naturalize may not be closely linked to ones attachment to Australia or the costs of returning home again. On the other hand, immigrants who have given up their original citizenship to become Australia citizens are more much likely to face high costs of return migration. These costs are then reflected in the proportion of individuals who choose to remain in Australia after retirement.

\section{Conclusions}

This paper analyzes the relationship between immigrants' retirement status and the prevalence of return migration from Australia to their country of origin. Understanding this relationship is important because immigrants' decisions about when to retire and where to spend their retirement years drives the extent to which immigrant aging will result in an increased demand for health care or old-age pensions.

Our theoretical model demonstrates that under reasonable conditions the incentives to return migrate are greatest at retirement implying that there is a direct link between the 
prevalence of return migration among and the retirement status of different immigrant populations. Our empirical results indicate that immigrants to Australia are more likely to be retired than are native-born Australians. This nativity gap in retirement status persists despite extensive controls for demographic, human capital, and family characteristics and is especially large for immigrant women. Immigrants' propensity to be retired decreases as the return migration rate of their countrymen increases, however. This relationship is strongest for men, for those who are close to retirement age and for with the highest cost of return migration.

These results point to several important policy conclusions. First, as return migration rates vary substantially across sending countries, it is also the case that the age structure and composition of the domestic labor force in the years ahead rests fundamentally on the national origin mix of today's immigration flow. In short, immigrant selection policies have direct consequences for the funding of old age pensions. Moreover, institutional arrangements surrounding the eligibility for citizenship, access to (and portability of) pensions, the provision of health care, etc. are likely to affect the net benefits to return migration and will therefore have far reaching consequences for the age composition of the immigrant population. Most of these relationships have received little attention and are not yet well understood. Modeling the linkages between return migration and retirement behavior (as we have done here), however, provides a useful way of beginning to think about the complex relationships between a range of domestic policies and demographic transitions within the immigrant population.

At the same time, these results leave open a number of important questions for future research. In particular, while some researchers have linked return migration to the incentives to accumulate savings or to send remittances (e.g. Galor and Stark 1990; Dustmann 1997b; Stark et al. 1997), it would be useful to understand how the potential for return migration is 
linked to the specific ways that immigrants fund their retirement. It seems sensible to expect that immigrants who intend to return home will have strong incentives to diversify their risk by saving both at home and abroad (Dustmann 1997b; Osili 2007). But what does this imply about the types of assets that immigrants hold? To what extent are decisions about home ownership or financial assets driven by expectations regarding return migration? Answers to these questions are important because consumption expenditures depend not only on wealth levels, but also on the composition of wealth, and because assets differ in terms of their expected rates of return, riskiness, and liquidity leading them to serve different functions in providing for a household's financial security (Cobb-Clark and Hildebrand in press).

Finally, we need to know more about gender differences in immigrants' patterns of retirement and return migration. Making progress in this area is likely to require a household perspective of the return migration decision similar to that used to understand the initial immigration process (Mincer 1978). Our results, for example, point to a much closer relationship between the level of return migration and the retirement status of immigrant men. This may suggest that for many women the decision to return migrate - like the initial decision to immigrate - is based on family (rather than individual returns). Moreover, women's retirement also needs to be understood in a household context. Specifically, we need to know more about the ways in which expectations regarding return migration, cultural differences in attitudes towards women, gender differences in assimilation profiles, etc. lead the age profile of retirement to differ for immigrant men and women. 


\section{References:}

Australian Bureau of Statistics (ABS) no date. Birthplace of Individual by Sex, Counts of Persons for Australia, 2001 Census Classification Counts. Commonwealth of Australia, Catalogue, 2022.0. - downloaded at www.abs.gov.au

Australian Bureau of Statistics (ABS) 2003. Expanded Community Profile, 2001 Census Community Profile Series. Commonwealth of Australia, Catalogue, 2005.0.

Australian Bureau of Statistics (ABS) 2007a. Country of Birth of Person (Full Classification List) by Sex, 2006 Census of Population and Housing. Commonwealth of Australia, Catalogue, 2068.0.

Australian Bureau of Statistics (ABS) 2007b. Country of Birth of Person by Age by Sex, 2006 Census of Population and Housing. Commonwealth of Australia, Catalogue, 2068.0.

Baker, Michael, and Dwayne Benjamin. 1997, "The Role of the Family in Immigrants' Labour Market Activity: An Evaluation of Alternative Explanations." American Economic Review, 87(4), pp.705-27.

Bauer, Thomas K., Cobb-Clark, Deborah. A., Hildebrand, Vincent. and Sinning, Mathis, in press, "A Comparative Analysis of the Nativity Wealth Gap", Economic Inquiry, forthcoming.

Brenchley, Fred, 2000. "Subject to Change”, The Bulletin, 6 June 2000.

Blau, Francine D., Kahn, Lawrence M., Moriarty, Joan Y. and Souza, Andre Portela, 2003, "The Role of the Family in Immigrants' Labour-Market Activity: Evidence from the United States", American Economic Review, Vol. 91(1), March, pp. 429-447.

Blau, Francine D., Kahn, Lawrence M., and Papps, Kerry L., 2008, "Gender Source Country Characteristics and Labor Market Assimilation Among Immigrants: 1980 - 2000" IZA Discussion Paper 3725, October.

Bauer, Thomas K. and Sinning, Mathias, in press, "The Savings Behavior of Temporary and Permanent Migrants in Germany" Journal of Population Economics, forthcoming.

Borjas, George and Bratsberg, Bernt, 1996, "Who Leaves? The Outmigration of the ForeignBorn", The Review of Economics and Statistics, Vol. 78(1), February, pp. 165 - 176.

Cobb-Clark, Deborah A. and Crossley, Thomas F. YEAR, "Revisiting the Family Investment Hypothesis", Labour Economics, Vol. 11(3), June, pp. 373 - 393.

Cobb-Clark, Deborah A. and Stillman, Steven, in press, "The Retirement Expectations of Middle-Age Australians", Economic Record, forthcoming.

Cobb-Clark, Deborah A. and Hildebrand, Vincent A., in press, "The Asset Portfolios of Native-born and Foreign-born Australian Households", Economic Record, forthcoming. 
De Coulon, Augustin and Wolff, François-Charles, 2006, "The Location of Immigrants at Retirement: Stay/Return or 'Va-et-Vient'?” IZA Discussion Paper 2224, July.

Department of Immigration and Citizenship, 2007, Emigration 2006-07 Australia. Commonwealth of Australia, ISSN 1324-3411.

Djajić, Slobodan, 1989, "Migrants in a Guest-Worker System" Journal of Development Economics, Vol. 31, pp. 327 - 339.

Dustmann, Christian 1997a, "Differences in the Labor Market Behavior between Temporary and Permanent Migrant Women”, Labour Economics, Vol. 4, pp. 29 - 46.

Dustmann, Christian, 1997b, "Return Migration, Uncertainty and Precautionary Savings" Journal of Development Economics, Vol. 52, pp. 295-316.

Dustmann, Christian, 1999. "Temporary Migration, Human Capital and Language Fluency of Migrants", Scandinavian Journal of Economics, Vol. 101(2), pp. 297 - 314.

Dustmann, Christian, 2003a, "Children and Return Migration", Journal of Population Economics, Vol. 16, pp. 815-830.

Dustmann, Christian, 2003b, "Return Migration, Wage Differentials, and the Optimal Migration Duration", European Economic Review, Vol. 47, pp. 353-369.

Dustmann, Christian, 2007, "Return Migration, Investment in Children, and Intergenerational Mobility: Comparing Sons of Foreign and Native Born Fathers", IZA Discussion Paper 3080, September.

Dustmann, Christian and Kirchkamp, Oliver, 2002, "The Optimal Migration Duration and Activity Choice after Re-Migration” Journal of Development Economics, Vol. 67, pp. 351-372.

Dustmann, Christian and Weiss, Yoram, 2007, "Return Migration: Theory and Empirical Evidence from the UK", British Journal of Industrial Relations, Vol. 45(2), June, pp. $236-256$.

Galor, Oded and Stark, Oded, 1990, "Migrants' Savings, the Probability of Return Migration and Migrants' Performance", International Economic Review, Vol. 31(2), May, pp. 463-467.

Galor, Oded and Stark, Oded, 1991, “The Probability of Return Migration, Migrants' Work Effort, and Migrants' Performance", Journal of Development Economics, Vol. 35, pp. $399-405$.

Hill, John K., 1987, “Immigrant Decisions Concerning Duration of Stay and Migratory Frequency”, Journal of Development Economics, Vol. 25, pp. 221- 234.

Jasso, Guillermina and Rosenzweig, Mark, 1982, "Estimating the Emigration Rates of Legal Immigrants using Administrative and Survey Data: the 1971 Cohort of Immigrants to the United States", Demography, Vol. 19, pp. 279-290. 
Lumsdaine, Robin L. and Mitchell, Olivia S., 1999, "New Developments in the Economic Analysis of Retirement," in: O. Ashenfelter \& D. Card (ed.), Handbook of Labor Economics, edition 1, volume 3, chapter 49, pp. 3261-3307.

Merkle, Lucie and Zimmermann, Klaus F., 1992, "Savings Remittances, and Return Migration", Economic Letters, Vol. 38, pp. 77 - 81.

Mincer, Jacob, 1978, 'Family Migration Decisions', Journal of Political Economy, Vol. 86, pp. 749-773.

Moulton, B., 1990, "An Illustration of a Pitfall in Estimating the Effects of Aggregate Variables on Micro Units," Review of Economics and Statistics, pp. 334-338.

Osili, Una Okonkwo, 2007, "Remittances and Savings from International Migration: Theory and Evidence Using A Matched Sample", Journal of Development Economics, Vol. 83 , pp. $446-465$.

Renshon, Stanley, 2000, "Dual Citizens in America: An Issue of Vast Proportions and Broad Significance", Backgrounder, Center for Immigration Studies, Washington, USA, July.

Schmidley, D. A. 2001. Profile of the Foreign-Born Population in the United States, 2000. Current Population Reports, Series P23-206. U.S. Census Bureau, Washington, DC: U.S. Government Printing Office.

Schoeni, Robert F., 1998, "Labor Market Assimilation of Immigrant Women" Industrial and Labor Relations Review, Vol. 51(3), April, pp. 483 - 504.

Sinning, Mathias, 2007, Determinants of Savings and Remittances: Empirical Evidence from Immigrants to Germany" IZA Discussion Paper, August.

Stark, Oded, Helmenstein, Christian, and Yegorov, Yury, 1997, "Migrants' Savings, Purchasing Power Parity, and the Optimal Duration of Migration" International Tax and Public Finance, Vol. 4, pp. 307-324.

United Nations (UN) 2006. Trends in Total Migrant Stock: The 2005 Revision CC-ROM Documentation, Department of Economic and Social Affairs, Population Division February 2006.

Warren, Robert and Peck, Jennifer M., 1980, "Foreign-born Emigration from the United States", Demography, Vol. 17, pp. $71-84$.

Wooden, M., Friden, S., and Watson, N., 2002. "The Household Income and Labour Dynamics in Australia (HILDA) Survey: Wave 1" Australian Economic Review, Vol. 35(3), pp. 339-348. 

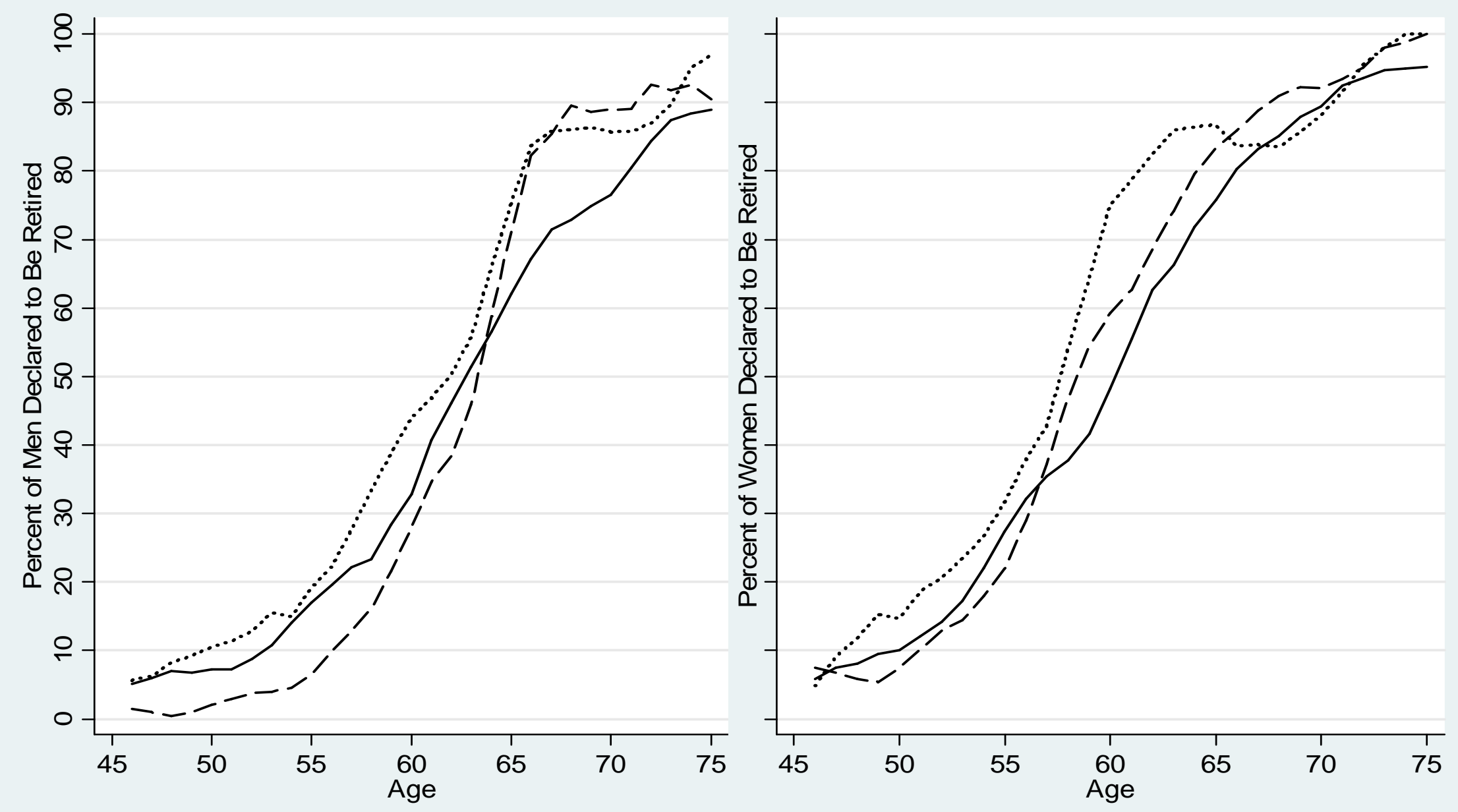

\section{Australian Born} ----. English Speaking Background Non-English Speaking Background

Figure 1: Percent Retired by Age, Gender and Immigrant Status 

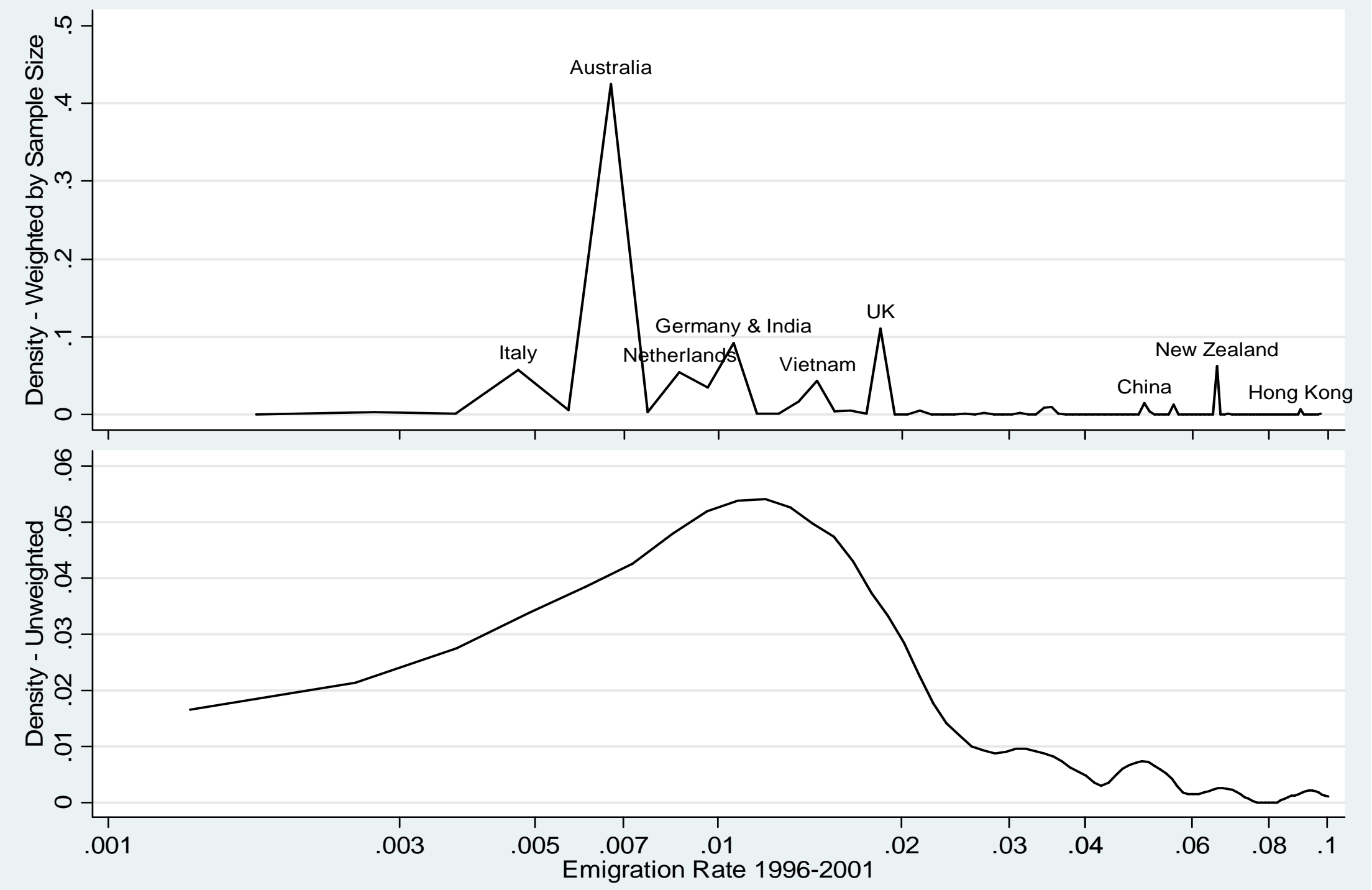

Figure 2: Distribution of Emigration Rates Across Countries 

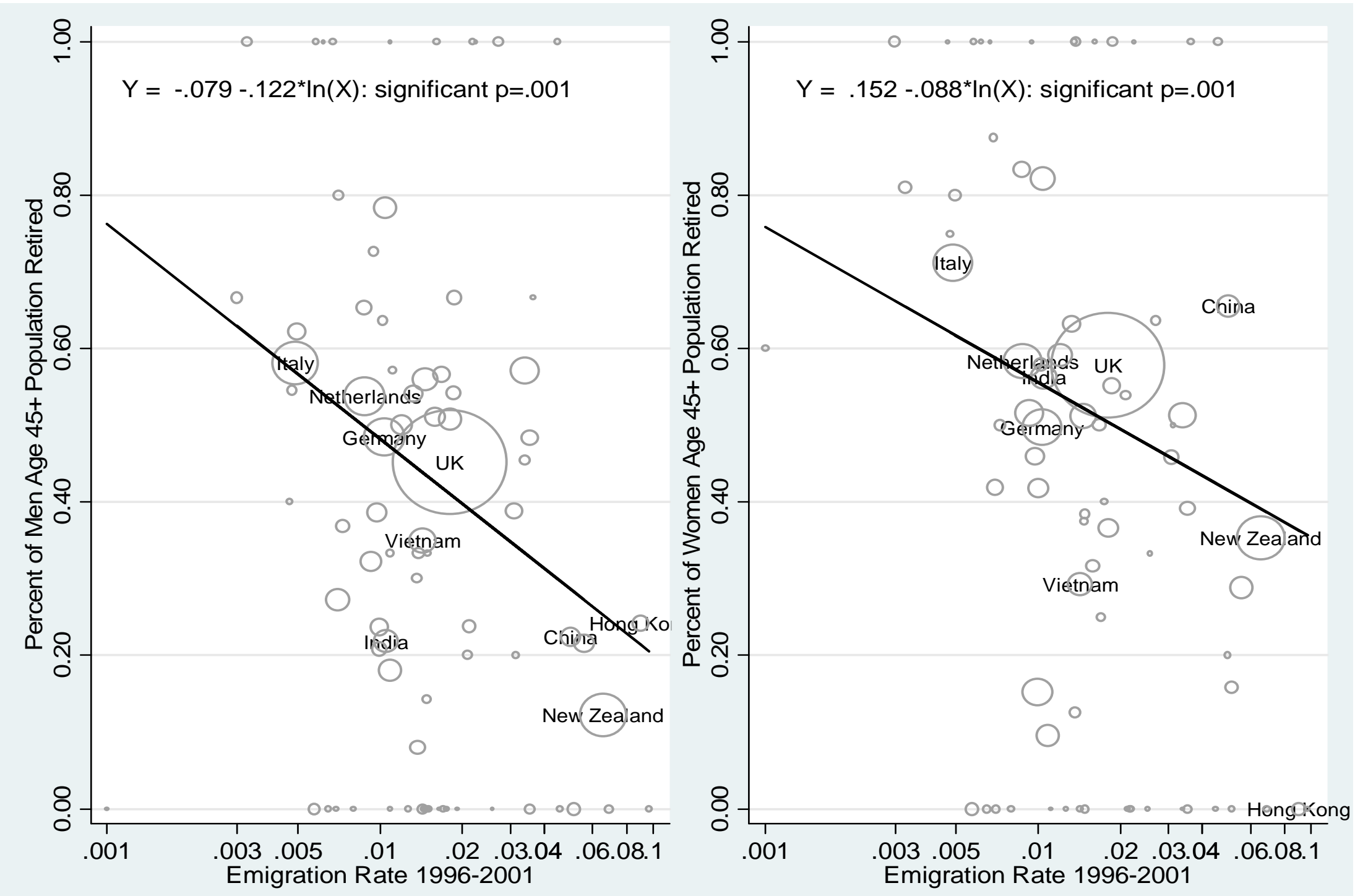

Figure 3: The Relationship between Retirement Rates and Emigration Rates Across Countries by Gender 

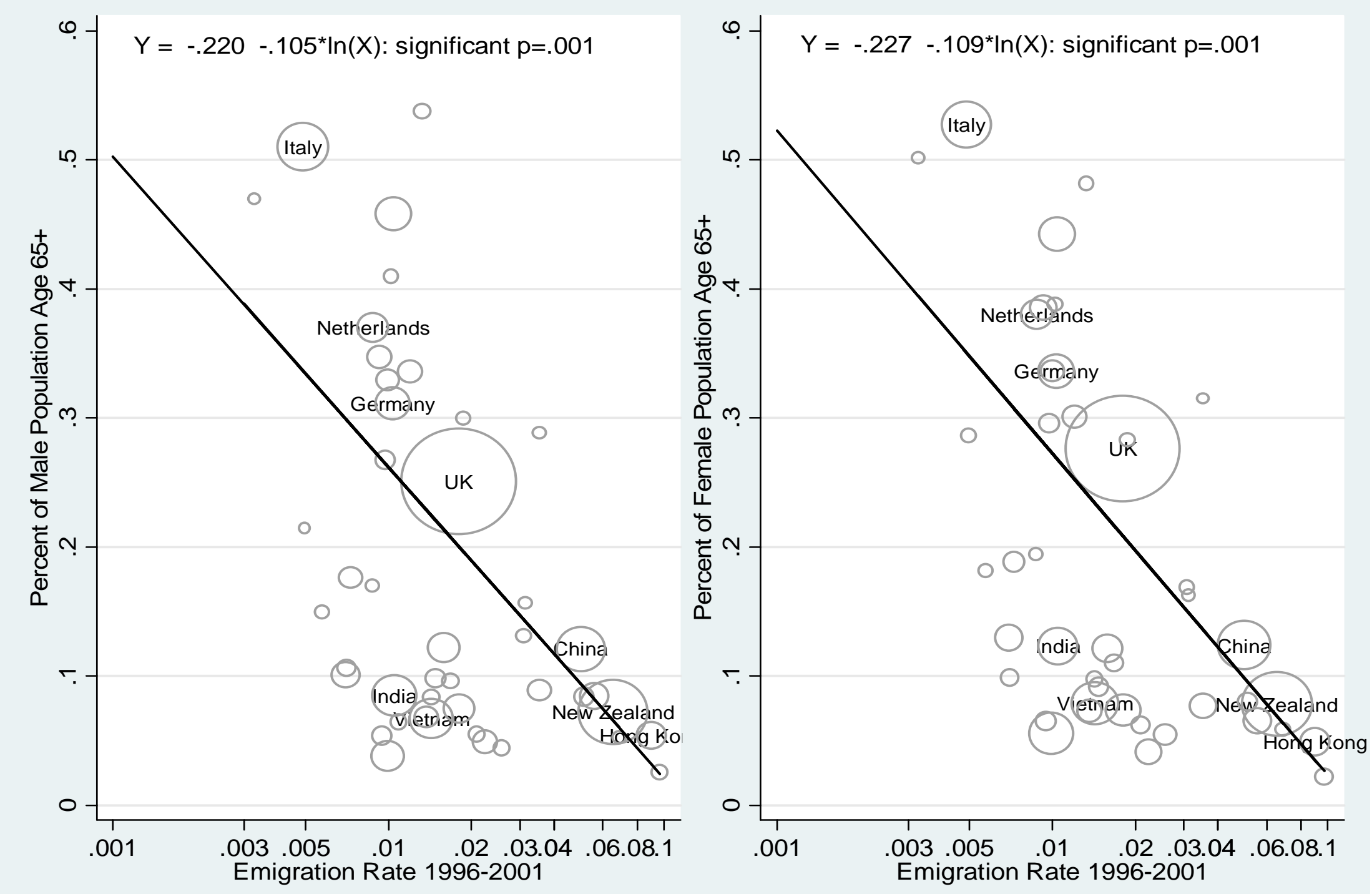

Figure 4: The Relationship between Population Composition and Emigration Rates Across Countries by Gender 
Table 1: Percent Retired by Gender and Immigration Status

\begin{tabular}{lccc}
\hline & Australian Born & $\begin{array}{c}\text { English Speaking } \\
\text { Background }\end{array}$ & $\begin{array}{c}\text { Non-English Speaking } \\
\text { Background }\end{array}$ \\
\hline Men & 0.39 & 0.40 & 0.45 \\
& $(0.01)$ & $(0.01)$ & $(0.01)$ \\
\hline Observations & 9,344 & 2,016 & 604 \\
Individuals & 2,467 & 518 & $17 \%$ \\
Percent of Individuals & $69 \%$ & $14 \%$ & 0.51 \\
\hline Women & 0.47 & 0.52 & $(0.01)$ \\
\hline Observations & $(0.00)$ & $(0.01)$ & 1,830 \\
Individuals & 10,266 & 1,913 & 537 \\
Percent of Individuals & 2,650 & 495 & $15 \%$ \\
\hline
\end{tabular}

Note: See the paper for further information about how the sample is created and variables are defined. 
Table 2: Probit Model of Likelihood of Being Retired Stratified by Gender (Marginal Effects and Standard Errors)

\begin{tabular}{|c|c|c|c|c|c|c|}
\hline & \multicolumn{3}{|c|}{ Men } & \multicolumn{3}{|c|}{ Women } \\
\hline & Base Model & $\begin{array}{c}\text { Indv/Hhold } \\
\text { Controls }\end{array}$ & $\begin{array}{c}\text { Emigration } \\
\text { Rate }\end{array}$ & Base Model & $\begin{array}{c}\text { Indv/Hhold } \\
\text { Controls }\end{array}$ & $\begin{array}{c}\text { Emigration } \\
\text { Rate }\end{array}$ \\
\hline English Bckgrnd Immigrant & $\begin{array}{c}0.023 \\
(0.057)\end{array}$ & $\begin{array}{l}-0.023 \\
(0.035)\end{array}$ & $\begin{array}{l}0.074+ \\
(0.042)\end{array}$ & $\begin{array}{c}0.048 \\
(0.054)\end{array}$ & $\begin{array}{c}0.090 * * \\
(0.028)\end{array}$ & $\begin{array}{l}0.132^{*} \\
(0.052)\end{array}$ \\
\hline Other Immigrants & $\begin{array}{c}0.086^{* *} * \\
(0.027)\end{array}$ & $\begin{array}{l}0.039+ \\
(0.020) \\
\end{array}$ & $\begin{array}{c}0.084 * * \\
(0.025) \\
\end{array}$ & $\begin{array}{c}0.041 \\
(0.035) \\
\end{array}$ & $\begin{array}{c}0.084 * * \\
(0.027)\end{array}$ & $\begin{array}{c}0.103 * * \\
(0.033)\end{array}$ \\
\hline Log Emigration Rate & & & $\begin{array}{l}-0.076^{*} \\
(0.032)\end{array}$ & & & $\begin{array}{l}-0.034 \\
(0.037)\end{array}$ \\
\hline$\overline{\text { Age }}$ & & $\begin{array}{c}0.105 * * \\
(0.020)\end{array}$ & $\begin{array}{c}0.106^{* *} \\
(0.020)\end{array}$ & & $\begin{array}{c}0.093 * * \\
(0.008)\end{array}$ & $\begin{array}{c}0.093 * * \\
(0.008)\end{array}$ \\
\hline Age-Squared / 100 & & $\begin{array}{l}-0.019 \\
(0.017)\end{array}$ & $\begin{array}{l}-0.020 \\
(0.017)\end{array}$ & & $\begin{array}{c}-0.029 * * \\
(0.008)\end{array}$ & $\begin{array}{c}-0.030 * * \\
(0.008)\end{array}$ \\
\hline Combined Effect at Age 60 & & $\begin{array}{c}0.081 * * \\
(0.002)\end{array}$ & $\begin{array}{c}0.081 * * \\
(0.002)\end{array}$ & & $\begin{array}{c}0.056 * * \\
(0.002)\end{array}$ & $\begin{array}{c}0.056 * * \\
(0.002)\end{array}$ \\
\hline Years of Work Experience & & $\begin{array}{c}-0.009 \\
(0.005)\end{array}$ & $\begin{array}{c}-0.009 \\
(0.005)\end{array}$ & & $\begin{array}{c}-0.013 * * \\
(0.002)\end{array}$ & $\begin{array}{c}-0.013 * * \\
(0.002)\end{array}$ \\
\hline Work Exp-Squared/100 & & $\begin{array}{c}-0.046^{* *} \\
(0.010)\end{array}$ & $\begin{array}{c}-0.046^{* *} \\
(0.010)\end{array}$ & & $\begin{array}{c}-0.006+ \\
(0.003)\end{array}$ & $\begin{array}{c}-0.006+ \\
(0.003)\end{array}$ \\
\hline Combined Eff at $38(\mathrm{M}) / 25(\mathrm{~W})$ & & $\begin{array}{c}-0.044 * * \\
(0.003)\end{array}$ & $\begin{array}{c}-0.044 * * \\
(0.003)\end{array}$ & & $\begin{array}{c}-0.016 * * \\
(0.001)\end{array}$ & $\begin{array}{c}-0.016^{* *} \\
(0.001)\end{array}$ \\
\hline $\mathrm{Ed}=$ Year 12 & & $\begin{array}{c}-0.151 * * \\
(0.026)\end{array}$ & $\begin{array}{c}-0.150 * * \\
(0.026)\end{array}$ & & $\begin{array}{c}-0.085 * * \\
(0.032)\end{array}$ & $\begin{array}{c}-0.082 * \\
(0.034)\end{array}$ \\
\hline $\mathrm{Ed}=$ Certificate & & $\begin{array}{c}-0.065^{* *} \\
(0.010)\end{array}$ & $\begin{array}{c}-0.065^{* *} \\
(0.010)\end{array}$ & & $\begin{array}{c}-0.074 * * \\
(0.013)\end{array}$ & $\begin{array}{c}-0.074 * * \\
(0.013)\end{array}$ \\
\hline $\mathrm{Ed}=$ Tertiary & & $\begin{array}{c}-0.280 * * \\
(0.017)\end{array}$ & $\begin{array}{c}-0.279 * * \\
(0.018)\end{array}$ & & $\begin{array}{c}-0.275^{*} * \\
(0.029)\end{array}$ & $\begin{array}{c}-0.272 * * \\
(0.027)\end{array}$ \\
\hline Good Health & & $\begin{array}{c}0.024 \\
(0.046)\end{array}$ & $\begin{array}{c}0.025 \\
(0.047)\end{array}$ & & $\begin{array}{c}0.023 \\
(0.031)\end{array}$ & $\begin{array}{c}0.023 \\
(0.031)\end{array}$ \\
\hline Average Health & & $\begin{array}{l}0.095+ \\
(0.057)\end{array}$ & $\begin{array}{l}0.095+ \\
(0.057)\end{array}$ & & $\begin{array}{c}0.119 * * \\
(0.042)\end{array}$ & $\begin{array}{c}0.120 * * \\
(0.042)\end{array}$ \\
\hline Fair / Poor Health & & $\begin{array}{c}0.361 * * \\
(0.033)\end{array}$ & $\begin{array}{c}0.361 * * \\
(0.033)\end{array}$ & & $\begin{array}{c}0.305 * * \\
(0.036)\end{array}$ & $\begin{array}{c}0.305 * * \\
(0.036)\end{array}$ \\
\hline Missing Health / SCQ & & $\begin{array}{c}0.169 * * \\
(0.058)\end{array}$ & $\begin{array}{c}0.171 * * \\
(0.059)\end{array}$ & & $\begin{array}{c}0.181 * * \\
(0.054)\end{array}$ & $\begin{array}{c}0.181 * * \\
(0.054)\end{array}$ \\
\hline Married/Cohab & & $\begin{array}{c}-0.106^{* *} \\
(0.023)\end{array}$ & $\begin{array}{c}-0.107 * * \\
(0.023)\end{array}$ & & $\begin{array}{c}0.079 * * \\
(0.030)\end{array}$ & $\begin{array}{c}0.079 * * \\
(0.030)\end{array}$ \\
\hline Years Partnered/10 & & $\begin{array}{c}0.029 * * \\
(0.007)\end{array}$ & $\begin{array}{c}0.028 * * \\
(0.007)\end{array}$ & & $\begin{array}{c}0.001 \\
(0.008)\end{array}$ & $\begin{array}{c}0.000 \\
(0.008)\end{array}$ \\
\hline Combined Eff at 30 Years & & $\begin{array}{l}-0.020 \\
(0.014)\end{array}$ & $\begin{array}{l}-0.022 \\
(0.014)\end{array}$ & & $\begin{array}{c}0.079 * * \\
(0.014)\end{array}$ & $\begin{array}{c}0.079 * * \\
(0.015)\end{array}$ \\
\hline Number Kids 0-15 & & $\begin{array}{c}0.004 \\
(0.007)\end{array}$ & $\begin{array}{c}0.005 \\
(0.007)\end{array}$ & & $\begin{array}{c}0.002 \\
(0.008)\end{array}$ & $\begin{array}{c}0.002 \\
(0.008)\end{array}$ \\
\hline Number Kids $16-20$ & & $\begin{array}{c}-0.066^{*} \\
(0.026)\end{array}$ & $\begin{array}{c}-0.065^{*} \\
(0.026)\end{array}$ & & $\begin{array}{c}-0.080 * * \\
(0.010)\end{array}$ & $\begin{array}{c}-0.080 * * \\
(0.009)\end{array}$ \\
\hline Number Adults 21+ & & $\begin{array}{c}-0.031 * * \\
(0.012)\end{array}$ & $\begin{array}{c}-0.030 * * \\
(0.011)\end{array}$ & & $\begin{array}{c}-0.029 * * \\
(0.007)\end{array}$ & $\begin{array}{c}-0.029 * * \\
(0.007) \\
\end{array}$ \\
\hline Pseudo R-squared & 0.005 & 0.580 & 0.580 & 0.005 & 0.547 & 0.547 \\
\hline Observations & 13,399 & 13,399 & 13,399 & 14,009 & 14,009 & 14,009 \\
\hline
\end{tabular}

Note: Robust standard errors in parentheses that allow for clustering for at the disaggregate country level which includes accounting for clustering of individuals across time. ${ }^{* *} \mathrm{p}<0.01, * \mathrm{p}<0.05,+\mathrm{p}<0.1$. All regressions include year, region and remoteness dummies. The three row labelled 'combined eff' present the total marginal effect implied by the coefficients on both the linear and squared age terms, by the coefficients on both the linear and squared work experience terms, and by the coefficients on both the indicator variables for being married and the linear term for length of marriage, evaluated at particular points in the distribution of these variables. 
Table 3: Predicted Probability of Being Retired for Individual with Mean Characteristics from Different Countries by Gender

\begin{tabular}{lccc}
\hline & Emigration Rate & Men & Women \\
\hline Italy & 0.005 & 0.482 & 0.633 \\
Netherlands & 0.009 & 0.436 & 0.614 \\
Germany & 0.010 & 0.423 & 0.609 \\
India & 0.011 & 0.422 & 0.608 \\
Vietnam & 0.014 & 0.398 & 0.598 \\
United Kingdom & 0.018 & 0.371 & 0.620 \\
China & 0.050 & 0.306 & 0.557 \\
New Zealand & 0.065 & 0.279 & 0.578 \\
Hong Kong & 0.090 & 0.266 & 0.537 \\
\hline Australia & NA & 0.379 & 0.522
\end{tabular}

Note: Predicted probabilities are calculated using the coefficients from the third specification in Table 2, setting all characteristics to the sample mean by gender besides the immigrant status indicator variables and the emigration rate, which are both set to the appropriate level for a particular country. The UK and New Zealand are the only countries with an English-speaking background. 
Table 4: Predicted Probability of Being Retired for Individual with Mean Characteristics from Different Countries by Gender and Age-Group

\begin{tabular}{|c|c|c|c|c|c|c|c|c|c|}
\hline & \multirow{2}{*}{$\begin{array}{c}\text { Emigration } \\
\text { Rate }\end{array}$} & \multicolumn{4}{|c|}{ Men } & \multicolumn{4}{|c|}{ Women } \\
\hline & & Age $<60$ & Age 60-64 & Age 65-69 & Age $>69$ & Age $<55$ & Age 55-59 & Age $60-64$ & Age $>64$ \\
\hline Italy & 0.005 & 0.084 & 0.511 & 0.924 & 0.981 & 0.061 & 0.387 & 0.900 & 0.985 \\
\hline Netherlands & 0.009 & 0.057 & 0.511 & 0.878 & 0.982 & 0.055 & 0.387 & 0.860 & 0.985 \\
\hline Germany & 0.010 & 0.051 & 0.511 & 0.862 & 0.982 & 0.053 & 0.387 & 0.846 & 0.985 \\
\hline India & 0.011 & 0.051 & 0.511 & NA & 0.982 & 0.053 & 0.387 & 0.845 & 0.985 \\
\hline Vietnam & 0.014 & 0.041 & 0.511 & 0.827 & 0.983 & 0.050 & 0.387 & 0.818 & NA \\
\hline United Kingdom & 0.018 & 0.026 & 0.416 & 0.947 & 0.980 & 0.061 & 0.347 & 0.782 & 0.992 \\
\hline China & 0.050 & 0.015 & 0.510 & 0.646 & 0.984 & 0.038 & 0.387 & 0.683 & 0.986 \\
\hline New Zealand & 0.065 & 0.009 & 0.416 & 0.848 & 0.981 & 0.048 & 0.347 & 0.631 & 0.992 \\
\hline Hong Kong & 0.090 & 0.009 & 0.510 & 0.542 & $\mathrm{NA}$ & 0.034 & 0.387 & 0.607 & 0.986 \\
\hline Australia & NA & 0.043 & 0.444 & 0.811 & 0.976 & 0.047 & 0.319 & 0.619 & 0.979 \\
\hline
\end{tabular}

Note: Predicted probabilities are calculated using the coefficients from the third specification in Table 4, setting all characteristics to the sample mean by gender and agegroup besides the immigrant status indicator variables and the emigration rate, which are both set to the appropriate level for a particular country. The UK and New Zealand are the only countries with an English-speaking background. Cells with 'NA' indicate that there are no immigrants in HILDA from a particularly country in that gender and age-group. 
Table 5: Predicted Probability of Being Retired for Individual with Mean Characteristics from Different Countries by Gender and Age-Group

\begin{tabular}{|c|c|c|c|c|c|c|c|c|c|c|c|c|}
\hline \multicolumn{13}{|c|}{ Men } \\
\hline & Emigration & Allows Dual & \multicolumn{2}{|c|}{ Overall } & \multicolumn{2}{|c|}{ Age $<60$} & \multicolumn{2}{|c|}{ Age 60-64 } & \multicolumn{2}{|c|}{ Age 65-69 } & \multicolumn{2}{|c|}{ Age $>69$} \\
\hline & Rate & Citizenship & OZ Citizen & Non-Citizen & OZ Citizen & Non-Citizen & OZ Citizen & Non-Citizen & OZ Citizen & Non-Citizen & OZ Citizen & Non-Citizen \\
\hline Germany & 0.010 & No & 0.615 & 0.366 & 0.208 & 0.034 & 0.611 & 0.366 & 0.865 & 0.917 & NA & NA \\
\hline India & 0.011 & No & 0.614 & 0.365 & 0.206 & 0.033 & 0.609 & 0.365 & NA & NA & NA & NA \\
\hline Vietnam & 0.014 & No & 0.580 & 0.333 & 0.164 & 0.023 & NA & NA & 0.841 & 0.900 & NA & NA \\
\hline China & 0.050 & No & 0.442 & 0.217 & 0.054 & 0.004 & 0.476 & 0.247 & NA & NA & NA & NA \\
\hline Italy & 0.005 & Yes & 0.520 & 0.504 & 0.142 & 0.092 & 0.518 & 0.600 & 0.987 & 0.943 & 0.961 & 0.984 \\
\hline Netherlands & 0.009 & Yes & 0.455 & 0.439 & 0.086 & 0.052 & 0.468 & 0.550 & 0.979 & 0.918 & 0.959 & 0.982 \\
\hline United Kingdom & 0.018 & Yes & 0.377 & 0.362 & 0.042 & 0.024 & 0.407 & 0.488 & 0.964 & 0.877 & 0.956 & 0.981 \\
\hline New Zealand & 0.065 & Yes & 0.250 & 0.238 & 0.009 & 0.004 & 0.303 & 0.379 & 0.918 & 0.773 & 0.951 & 0.978 \\
\hline \multicolumn{13}{|c|}{ Women } \\
\hline & Emigration & Allows Dual & \multicolumn{2}{|c|}{ Overall } & \multicolumn{2}{|c|}{ Age $<55$} & \multicolumn{2}{|c|}{ Age 55-59 } & \multicolumn{2}{|c|}{ Age 60-64 } & \multicolumn{2}{|c|}{ Age $>64$} \\
\hline & Rate & Citizenship & OZ Citizen & Non-Citizen & OZ Citizen & Non-Citizen & OZ Citizen & Non-Citizen & OZ Citizen & Non-Citizen & OZ Citizen & Non-Citizen \\
\hline Germany & 0.010 & No & 0.712 & 0.579 & 0.073 & 0.038 & 0.393 & 0.341 & $\mathrm{NA}$ & NA & NA & $\mathrm{NA}$ \\
\hline India & 0.011 & No & 0.712 & 0.579 & 0.073 & 0.038 & 0.393 & 0.342 & NA & NA & NA & NA \\
\hline Vietnam & 0.014 & No & 0.710 & 0.576 & 0.075 & 0.040 & 0.395 & 0.343 & NA & NA & NA & NA \\
\hline China & 0.050 & No & 0.699 & 0.564 & 0.086 & 0.046 & 0.403 & 0.351 & NA & NA & NA & NA \\
\hline Italy & 0.005 & Yes & 0.628 & 0.621 & 0.047 & 0.040 & 0.336 & 0.343 & 0.825 & 0.856 & 0.994 & 0.992 \\
\hline Netherlands & 0.009 & Yes & 0.623 & 0.615 & 0.050 & 0.043 & 0.340 & 0.346 & 0.795 & 0.830 & 0.994 & 0.991 \\
\hline United Kingdom & 0.018 & Yes & 0.616 & 0.608 & 0.054 & 0.046 & 0.344 & 0.351 & 0.755 & 0.794 & 0.994 & 0.991 \\
\hline New Zealand & 0.065 & Yes & 0.604 & 0.596 & 0.062 & 0.053 & 0.352 & 0.359 & 0.674 & 0.719 & 0.993 & 0.990 \\
\hline
\end{tabular}

Note: Predicted probabilities are calculated using the coefficients from the second specification in Table 6, setting all characteristics to the sample mean by gender and agegroup besides the citizenship variables and the emigration rate, which are both set to the appropriate level for a particular country. Cells with 'NA' indicate that there are no immigrants in HILDA from a particularly country in that gender and age-group or that the interaction term was not identified in the regression model. 
Appendix Table 1: Characteristics by Gender and Immigration Status

\begin{tabular}{|c|c|c|c|c|c|c|}
\hline & \multicolumn{3}{|c|}{$\underline{\text { Men }}$} & \multicolumn{3}{|c|}{$\underline{\text { Women }}$} \\
\hline & $\begin{array}{c}\text { Australian } \\
\text { Born }\end{array}$ & $\begin{array}{c}\text { English } \\
\text { Speaking } \\
\text { Background }\end{array}$ & $\begin{array}{l}\text { Non-English } \\
\text { Speaking } \\
\text { Background }\end{array}$ & $\begin{array}{c}\text { Australian } \\
\text { Born }\end{array}$ & $\begin{array}{c}\text { English } \\
\text { Speaking } \\
\text { Background }\end{array}$ & $\begin{array}{l}\text { Non-English } \\
\text { Speaking } \\
\text { Background }\end{array}$ \\
\hline Age & $\begin{array}{l}59.7 \\
(0.1)\end{array}$ & $\begin{array}{l}61.0 \\
(0.2)\end{array}$ & $\begin{array}{l}60.0 \\
(0.2)\end{array}$ & $\begin{array}{l}60.4 \\
(0.1)\end{array}$ & $\begin{array}{l}60.8 \\
(0.3)\end{array}$ & $\begin{array}{l}59.2 \\
(0.2)\end{array}$ \\
\hline Years of Work Experience & $\begin{array}{l}38.0 \\
(0.1)\end{array}$ & $\begin{array}{l}38.6 \\
(0.2) \\
\end{array}$ & $\begin{array}{l}35.6 \\
(0.2)\end{array}$ & $\begin{array}{l}25.1 \\
(0.1)\end{array}$ & $\begin{array}{l}28.2 \\
(0.3)\end{array}$ & $\begin{array}{l}25.1 \\
(0.3)\end{array}$ \\
\hline $\mathrm{Ed}=$ Year 11 or less & $\begin{array}{c}0.38 \\
(0.01)\end{array}$ & $\begin{array}{c}0.28 \\
(0.01)\end{array}$ & $\begin{array}{c}0.26 \\
(0.01)\end{array}$ & $\begin{array}{c}0.56 \\
(0.00)\end{array}$ & $\begin{array}{c}0.43 \\
(0.01)\end{array}$ & $\begin{array}{c}0.43 \\
(0.01)\end{array}$ \\
\hline $\mathrm{Ed}=$ Year 12 & $\begin{array}{c}0.07 \\
(0.00)\end{array}$ & $\begin{array}{c}0.07 \\
(0.01)\end{array}$ & $\begin{array}{c}0.13 \\
(0.01)\end{array}$ & $\begin{array}{c}0.07 \\
(0.00)\end{array}$ & $\begin{array}{c}0.12 \\
(0.01)\end{array}$ & $\begin{array}{c}0.17 \\
(0.01)\end{array}$ \\
\hline $\mathrm{Ed}=$ Certificate & $\begin{array}{c}0.38 \\
(0.01)\end{array}$ & $\begin{array}{c}0.46 \\
(0.01)\end{array}$ & $\begin{array}{c}0.38 \\
(0.01)\end{array}$ & $\begin{array}{c}0.21 \\
(0.00)\end{array}$ & $\begin{array}{c}0.26 \\
(0.01)\end{array}$ & $\begin{array}{c}0.21 \\
(0.01)\end{array}$ \\
\hline $\mathrm{Ed}=$ Tertiary & $\begin{array}{c}0.17 \\
(0.00) \\
\end{array}$ & $\begin{array}{c}0.19 \\
(0.01) \\
\end{array}$ & $\begin{array}{c}0.22 \\
(0.01) \\
\end{array}$ & $\begin{array}{c}0.16 \\
(0.00) \\
\end{array}$ & $\begin{array}{c}0.18 \\
(0.01) \\
\end{array}$ & $\begin{array}{c}0.19 \\
(0.01) \\
\end{array}$ \\
\hline Excellent Health & $\begin{array}{c}0.07 \\
(0.00)\end{array}$ & $\begin{array}{c}0.08 \\
(0.01)\end{array}$ & $\begin{array}{c}0.06 \\
(0.01)\end{array}$ & $\begin{array}{c}0.07 \\
(0.00)\end{array}$ & $\begin{array}{c}0.08 \\
(0.01)\end{array}$ & $\begin{array}{c}0.05 \\
(0.01)\end{array}$ \\
\hline Good Health & $\begin{array}{c}0.28 \\
(0.00)\end{array}$ & $\begin{array}{c}0.28 \\
(0.01)\end{array}$ & $\begin{array}{c}0.21 \\
(0.01)\end{array}$ & $\begin{array}{c}0.29 \\
(0.00)\end{array}$ & $\begin{array}{c}0.31 \\
(0.01)\end{array}$ & $\begin{array}{c}0.19 \\
(0.01)\end{array}$ \\
\hline Average Health & $\begin{array}{c}0.34 \\
(0.00)\end{array}$ & $\begin{array}{c}0.39 \\
(0.01)\end{array}$ & $\begin{array}{c}0.32 \\
(0.01)\end{array}$ & $\begin{array}{c}0.36 \\
(0.00)\end{array}$ & $\begin{array}{c}0.35 \\
(0.01)\end{array}$ & $\begin{array}{c}0.31 \\
(0.01)\end{array}$ \\
\hline Fair / Poor Health & $\begin{array}{c}0.24 \\
(0.00)\end{array}$ & $\begin{array}{c}0.18 \\
(0.01)\end{array}$ & $\begin{array}{c}0.26 \\
(0.01)\end{array}$ & $\begin{array}{c}0.22 \\
(0.00)\end{array}$ & $\begin{array}{c}0.19 \\
(0.01)\end{array}$ & $\begin{array}{c}0.28 \\
(0.01)\end{array}$ \\
\hline Missing Health / SCQ & $\begin{array}{c}0.07 \\
(0.00) \\
\end{array}$ & $\begin{array}{c}0.07 \\
(0.01) \\
\end{array}$ & $\begin{array}{c}0.15 \\
(0.01) \\
\end{array}$ & $\begin{array}{c}0.07 \\
(0.00) \\
\end{array}$ & $\begin{array}{c}0.07 \\
(0.01) \\
\end{array}$ & $\begin{array}{c}0.17 \\
(0.01) \\
\end{array}$ \\
\hline Married/Cohab & $\begin{array}{c}0.76 \\
(0.00)\end{array}$ & $\begin{array}{c}0.81 \\
(0.01)\end{array}$ & $\begin{array}{c}0.87 \\
(0.01)\end{array}$ & $\begin{array}{c}0.63 \\
(0.00)\end{array}$ & $\begin{array}{c}0.66 \\
(0.01)\end{array}$ & $\begin{array}{c}0.67 \\
(0.01)\end{array}$ \\
\hline Years if Married/Cohab & $\begin{array}{l}30.1 \\
(0.2) \\
\end{array}$ & $\begin{array}{l}30.0 \\
(0.4) \\
\end{array}$ & $\begin{array}{l}29.6 \\
(0.3) \\
\end{array}$ & $\begin{array}{l}31.6 \\
(0.2) \\
\end{array}$ & $\begin{array}{l}30.3 \\
(0.4) \\
\end{array}$ & $\begin{array}{l}30.3 \\
(0.4) \\
\end{array}$ \\
\hline Number Kids 0-15 & $\begin{array}{c}0.33 \\
(0.01)\end{array}$ & $\begin{array}{c}0.26 \\
(0.02)\end{array}$ & $\begin{array}{c}0.41 \\
(0.02)\end{array}$ & $\begin{array}{c}0.21 \\
(0.01)\end{array}$ & $\begin{array}{c}0.19 \\
(0.01)\end{array}$ & $\begin{array}{c}0.21 \\
(0.01)\end{array}$ \\
\hline Number Kids $16-20$ & $\begin{array}{c}0.19 \\
(0.01)\end{array}$ & $\begin{array}{c}0.13 \\
(0.01)\end{array}$ & $\begin{array}{c}0.23 \\
(0.01)\end{array}$ & $\begin{array}{c}0.17 \\
(0.00)\end{array}$ & $\begin{array}{c}0.14 \\
(0.01)\end{array}$ & $\begin{array}{c}0.20 \\
(0.01)\end{array}$ \\
\hline Number Adults 21+ & $\begin{array}{c}1.96 \\
(0.01) \\
\end{array}$ & $\begin{array}{c}1.96 \\
(0.01) \\
\end{array}$ & $\begin{array}{c}2.18 \\
(0.02) \\
\end{array}$ & $\begin{array}{c}1.85 \\
(0.01) \\
\end{array}$ & $\begin{array}{c}1.84 \\
(0.01) \\
\end{array}$ & $\begin{array}{c}2.02 \\
(0.02) \\
\end{array}$ \\
\hline Sydney & 0.13 & 0.18 & 0.24 & 0.16 & 0.18 & 0.23 \\
\hline Rest of NSW / ACT & 0.20 & 0.12 & 0.09 & 0.19 & 0.11 & 0.10 \\
\hline Melbourne & 0.14 & 0.13 & 0.30 & 0.15 & 0.16 & 0.30 \\
\hline Rest of Victoria / Tasmania & 0.14 & 0.07 & 0.04 & 0.13 & 0.07 & 0.06 \\
\hline Brisbane & 0.08 & 0.10 & 0.04 & 0.09 & 0.09 & 0.04 \\
\hline Rest of QLD & 0.12 & 0.10 & 0.06 & 0.10 & 0.10 & 0.04 \\
\hline South Australia & 0.10 & 0.12 & 0.08 & 0.09 & 0.13 & 0.12 \\
\hline Western Australia and NT & 0.09 & 0.18 & 0.14 & 0.09 & 0.16 & 0.10 \\
\hline Major City & 0.51 & 0.67 & 0.83 & 0.55 & 0.70 & 0.82 \\
\hline Inner Regional & 0.31 & 0.22 & 0.10 & 0.30 & 0.19 & 0.12 \\
\hline Outer Regional / Remote & 0.18 & 0.10 & 0.07 & 0.15 & 0.11 & 0.06 \\
\hline Observations & 9,344 & 2,016 & 2,039 & 10,266 & 1,913 & 1,830 \\
\hline Individuals & 2,467 & 518 & 604 & 2,650 & 495 & 537 \\
\hline Percent of Individuals & $69 \%$ & $14 \%$ & $17 \%$ & $72 \%$ & $13 \%$ & $15 \%$ \\
\hline
\end{tabular}

Note: See the paper for further information about how the sample is created and variables are defined. 
Appendix Table 2: Probit Model of Likelihood of Not Being Employed by Age-Group (Marginal Effects and Standard Errors)

\begin{tabular}{|c|c|c|c|c|c|c|c|c|c|c|}
\hline & \multicolumn{5}{|c|}{ Men } & \multicolumn{5}{|c|}{ Women } \\
\hline & Overall & Age 45-59 & Age 60-64 & Age 65-69 & Age $>69$ & Overall & Age $45-54$ & Age 55-59 & Age 60-64 & Age $>64$ \\
\hline \multirow[t]{2}{*}{ English Bckgrnd Immigrant } & $0.081^{*}$ & 0.027 & 0.022 & $0.161 * *$ & 0.008 & $0.107 *$ & 0.088 & 0.049 & $0.198 * *$ & $0.008 * *$ \\
\hline & $(0.040)$ & $(0.020)$ & $(0.062)$ & $(0.019)$ & $(0.006)$ & $(0.048)$ & $(0.072)$ & $(0.075)$ & $(0.029)$ & $(0.003)$ \\
\hline \multirow[t]{2}{*}{ Other Immigrants } & $0.087 * *$ & $0.059 * *$ & 0.071 & $0.073^{*}$ & -0.001 & $0.102 * *$ & $0.083+$ & 0.101 & $0.192 * *$ & 0.003 \\
\hline & $(0.030)$ & $(0.022)$ & $(0.048)$ & $(0.032)$ & $(0.008)$ & $(0.030)$ & $(0.043)$ & $(0.067)$ & $(0.037)$ & $(0.004)$ \\
\hline \multirow[t]{2}{*}{ Log Emigration Rate } & -0.040 & $-0.026^{*}$ & 0.025 & $-0.105^{*}$ & -0.001 & -0.009 & -0.010 & 0.014 & -0.046 & -0.003 \\
\hline & $(0.025)$ & $(0.013)$ & $(0.048)$ & $(0.046)$ & $(0.007)$ & $(0.032)$ & $(0.032)$ & $(0.048)$ & $(0.037)$ & $(0.004)$ \\
\hline \multirow[t]{2}{*}{$\overline{\text { Age }}$} & $0.051 * *$ & $0.039 * *$ & $0.105^{* *}$ & $0.052 * *$ & $0.006^{* *}$ & $0.034 * *$ & $0.028 * *$ & $0.037 * *$ & $0.054 * *$ & $0.003 * *$ \\
\hline & $(0.011)$ & $(0.001)$ & $(0.007)$ & $(0.006)$ & $(0.001)$ & $(0.007)$ & $(0.002)$ & $(0.007)$ & $(0.004)$ & 0.000 \\
\hline \multirow[t]{2}{*}{ Age-Squared/100 } & $0.029 * *$ & & & & & 0.010 & & & & \\
\hline & $(0.009)$ & & & & & $(0.007)$ & & & & \\
\hline \multirow{2}{*}{ Years of Work Experience } & $-0.014 * *$ & -0.001 & $0.127 * *$ & $0.104 * *$ & $0.005 * *$ & $-0.016^{* *}$ & $-0.020 * *$ & $-0.020 * *$ & -0.005 & $0.002 * *$ \\
\hline & $(0.005)$ & $(0.003)$ & $(0.014)$ & $(0.007)$ & $(0.001)$ & $(0.002)$ & $(0.004)$ & $(0.003)$ & $(0.003)$ & 0.000 \\
\hline \multirow[t]{2}{*}{ Work Exp-Squared/100 } & $-0.053 * *$ & $-0.041 * *$ & $-0.229 * *$ & $-0.155^{* *}$ & $-0.009 * *$ & -0.001 & 0.008 & 0.000 & $-0.015 * *$ & $-0.004 * *$ \\
\hline & $(0.009)$ & $(0.005)$ & $(0.020)$ & $(0.009)$ & $(0.001)$ & $(0.004)$ & $(0.010)$ & $(0.008)$ & $(0.006)$ & $(0.001)$ \\
\hline \multirow[t]{2}{*}{$\overline{E d}=$ Year 12} & $-0.138 * *$ & $-0.076^{* *}$ & -0.046 & 0.033 & $-0.015 * *$ & $-0.064+$ & -0.010 & -0.093 & -0.098 & -0.026 \\
\hline & $(0.020)$ & $(0.007)$ & (0.044) & $(0.043)$ & $(0.004)$ & $(0.038)$ & $(0.021)$ & $(0.062)$ & $(0.166)$ & $(0.021)$ \\
\hline \multirow{2}{*}{ Ed $=$ Certificate } & $-0.070 * *$ & $-0.066 * *$ & -0.015 & -0.029 & -0.002 & $-0.049 * *$ & -0.037 & $-0.051+$ & -0.058 & -0.002 \\
\hline & $(0.013)$ & $(0.005)$ & $(0.028)$ & $(0.020)$ & $(0.002)$ & $(0.012)$ & (0.028) & $(0.030)$ & $(0.051)$ & $(0.003)$ \\
\hline \multirow[t]{2}{*}{$\mathrm{Ed}=$ Tertiary } & $-0.330 * *$ & $-0.144 * *$ & $-0.322 * *$ & $-0.220 * *$ & $-0.060 * *$ & $-0.212 * *$ & $-0.127 * *$ & $-0.225 * *$ & $-0.084 * *$ & $-0.064 * *$ \\
\hline & $(0.017)$ & $(0.007)$ & $(0.033)$ & $(0.030)$ & $(0.013)$ & $(0.020)$ & $(0.011)$ & $(0.018)$ & $(0.026)$ & $(0.015)$ \\
\hline \multirow[t]{2}{*}{ Good Health } & 0.010 & $-0.027 *$ & $0.082^{*}$ & 0.025 & 0.011 & 0.009 & 0.017 & 0.004 & $-0.099+$ & 0.001 \\
\hline & $(0.035)$ & $(0.013)$ & $(0.040)$ & $(0.021)$ & $(0.007)$ & $(0.019)$ & $(0.015)$ & $(0.042)$ & $(0.056)$ & $(0.002)$ \\
\hline \multirow[t]{2}{*}{ Average Health } & $0.080 *$ & 0.005 & $0.120 *$ & $0.090 * *$ & 0.018 & $0.105 * *$ & $0.071 * *$ & $0.135^{*}$ & 0.019 & $0.010 * *$ \\
\hline & $(0.034)$ & $(0.014)$ & $(0.048)$ & $(0.015)$ & $(0.013)$ & $(0.026)$ & $(0.017)$ & $(0.068)$ & $(0.068)$ & $(0.002)$ \\
\hline \multirow[t]{2}{*}{ Fair / Poor Health } & $0.324 * *$ & $0.230 * *$ & $0.398 * *$ & $0.151 * *$ & 0.020 & $0.260 * *$ & $0.329 * *$ & $0.379 * *$ & $0.084+$ & $0.015^{* *}$ \\
\hline & $(0.021)$ & $(0.024)$ & $(0.023)$ & $(0.013)$ & $(0.013)$ & $(0.016)$ & $(0.028)$ & $(0.070)$ & $(0.048)$ & $(0.002)$ \\
\hline \multirow[t]{2}{*}{ Missing Health / SCQ } & $0.137 * *$ & $0.056+$ & $0.216^{* *}$ & $0.094 * *$ & $0.011+$ & $0.143^{* *}$ & $0.147 * *$ & $0.181 *$ & 0.020 & $0.010^{* *}$ \\
\hline & $(0.052)$ & $(0.029)$ & $(0.038)$ & $(0.025)$ & $(0.006)$ & $(0.020)$ & $(0.027)$ & $(0.090)$ & $(0.100)$ & $(0.002)$ \\
\hline Percent Not Employed & 0.448 & 0.180 & 0.518 & 0.772 & 0.918 & 0.554 & 0.225 & 0.443 & 0.690 & 0.939 \\
\hline Pseudo R-squared & 0.534 & 0.364 & 0.294 & 0.338 & 0.392 & 0.465 & 0.253 & 0.225 & 0.181 & 0.336 \\
\hline Observations & 13,399 & 7,303 & 1,737 & 1,396 & 2,963 & 14,009 & 5,470 & 2,182 & 1,657 & 4,700 \\
\hline
\end{tabular}

Note: Robust standard errors in parentheses that allow for clustering for individuals across time. $* * p<0.01, * p<0.05,+p<0.1$. All regressions include year, region and

remoteness dummies and controls for marital status and household composition. 
Appendix Table 3: Probit Model of Likelihood of Being Retired by Gender and Age-Group

(Marginal Effects and Standard Errors)

\begin{tabular}{|c|c|c|c|c|c|c|c|c|c|c|c|c|}
\hline & $\begin{array}{l}\text { Base } \\
\text { Model }\end{array}$ & $\begin{array}{l}\text { Indv/Hh } \\
\text { Controls }\end{array}$ & $\begin{array}{c}\text { Emigrat } \\
\text { Rate }\end{array}$ & $\begin{array}{l}\text { Base } \\
\text { Model }\end{array}$ & $\begin{array}{l}\text { Indv/Hh } \\
\text { Controls }\end{array}$ & $\begin{array}{c}\text { Emigrat } \\
\text { Rate }\end{array}$ & $\begin{array}{c}\text { Base } \\
\text { Model }\end{array}$ & $\begin{array}{l}\text { Indv/Hh } \\
\text { Controls }\end{array}$ & $\begin{array}{c}\text { Emigrat } \\
\text { Rate }\end{array}$ & $\begin{array}{l}\text { Base } \\
\text { Model }\end{array}$ & $\begin{array}{l}\text { Indv/Hh } \\
\text { Controls }\end{array}$ & $\begin{array}{c}\text { Emigrat } \\
\text { Rate }\end{array}$ \\
\hline \multicolumn{13}{|c|}{ Men } \\
\hline & \multicolumn{3}{|c|}{ Age $45-59$} & \multicolumn{3}{|c|}{ Age $60-64$} & \multicolumn{3}{|c|}{ Age 65-69 } & \multicolumn{3}{|c|}{ Age $>69$} \\
\hline English Bckgrnd Immigrant & $\begin{array}{c}-0.047 * * \\
(0.013)\end{array}$ & $\begin{array}{c}-0.022 * * \\
(0.007)\end{array}$ & $\begin{array}{c}0.013 \\
(0.018)\end{array}$ & $\begin{array}{l}-0.048 \\
(0.032)\end{array}$ & $\begin{array}{l}-0.028 \\
(0.031)\end{array}$ & $\begin{array}{c}-0.028 \\
(0.060)\end{array}$ & $\begin{array}{c}0.150^{* *} \\
(0.049)\end{array}$ & $\begin{array}{c}0.114 * * \\
(0.031)\end{array}$ & $\begin{array}{c}0.183 * * \\
(0.025)\end{array}$ & $\begin{array}{l}0.032^{*} \\
(0.013)\end{array}$ & $\begin{array}{c}0.004 \\
(0.006)\end{array}$ & $\begin{array}{c}0.003 \\
(0.011)\end{array}$ \\
\hline Other Immigrants & $\begin{array}{c}0.055^{* *} \\
(0.021)\end{array}$ & $\begin{array}{c}0.004 \\
(0.010)\end{array}$ & $\begin{array}{c}0.026 \\
(0.018)\end{array}$ & $\begin{array}{l}0.083+ \\
(0.049)\end{array}$ & $\begin{array}{c}0.067 \\
(0.043)\end{array}$ & $\begin{array}{c}0.067 \\
(0.045)\end{array}$ & $\begin{array}{c}0.155^{* *} \\
(0.033)\end{array}$ & $\begin{array}{c}0.042 \\
(0.037)\end{array}$ & $\begin{array}{l}0.090^{*} \\
(0.037)\end{array}$ & $\begin{array}{l}0.032+ \\
(0.018)\end{array}$ & $\begin{array}{c}0.006 \\
(0.009)\end{array}$ & $\begin{array}{c}0.006 \\
(0.010)\end{array}$ \\
\hline Log Emigration Rate & & & $\begin{array}{l}-0.029 * \\
(0.012)\end{array}$ & & & $\begin{array}{c}0.000 \\
(0.043)\end{array}$ & & & $\begin{array}{c}-0.108+ \\
(0.056)\end{array}$ & & & $\begin{array}{c}0.001 \\
(0.009)\end{array}$ \\
\hline Percent Declared Retired & & 0.109 & & & 0.457 & & & 0.750 & & & 0.907 & \\
\hline Pseudo R-squared & 0.025 & 0.401 & 0.403 & 0.015 & 0.269 & 0.269 & 0.038 & 0.322 & 0.327 & 0.032 & 0.349 & 0.349 \\
\hline Observations & 7,303 & 7,303 & 7,303 & 1,737 & 1,737 & 1,737 & 1,396 & 1,396 & 1,396 & 2,963 & 2,963 & 2,963 \\
\hline \multicolumn{13}{|c|}{ Women } \\
\hline & \multicolumn{3}{|c|}{ Age $45-54$} & \multicolumn{3}{|c|}{ Age $55-59$} & \multicolumn{3}{|c|}{ Age 60-64 } & \multicolumn{3}{|c|}{ Age $>64$} \\
\hline English Bckgrnd Immigrant & $\begin{array}{l}-0.007 \\
(0.017)\end{array}$ & $\begin{array}{c}0.012 \\
(0.013)\end{array}$ & $\begin{array}{c}0.028 \\
(0.028)\end{array}$ & $\begin{array}{c}0.007 \\
(0.058)\end{array}$ & $\begin{array}{c}0.028 \\
(0.033)\end{array}$ & $\begin{array}{c}0.028 \\
(0.079)\end{array}$ & $\begin{array}{c}0.099 * * \\
(0.025)\end{array}$ & $\begin{array}{c}0.132 * * \\
(0.015)\end{array}$ & $\begin{array}{c}0.251 * * \\
(0.042)\end{array}$ & $\begin{array}{l}0.023^{*} \\
(0.012)\end{array}$ & $\begin{array}{c}0.013 * * \\
(0.002)\end{array}$ & $\begin{array}{l}0.013^{*} \\
(0.005)\end{array}$ \\
\hline Other Immigrants & $\begin{array}{l}0.047 * \\
(0.022)\end{array}$ & $\begin{array}{c}0.005 \\
(0.011)\end{array}$ & $\begin{array}{c}0.012 \\
(0.016)\end{array}$ & $\begin{array}{c}0.098+ \\
(0.052)\end{array}$ & $\begin{array}{c}0.069 \\
(0.052)\end{array}$ & $\begin{array}{c}0.069 \\
(0.071)\end{array}$ & $\begin{array}{c}0.222 * * \\
(0.040)\end{array}$ & $\begin{array}{c}0.210^{* *} \\
(0.039)\end{array}$ & $\begin{array}{c}0.259 * * \\
(0.034)\end{array}$ & $\begin{array}{c}0.004 \\
(0.016)\end{array}$ & $\begin{array}{c}0.006 \\
(0.006)\end{array}$ & $\begin{array}{c}0.005 \\
(0.007)\end{array}$ \\
\hline Log Emigration Rate & & & $\begin{array}{c}-0.010 \\
(0.014)\end{array}$ & & & $\begin{array}{c}0.000 \\
(0.062)\end{array}$ & & & $\begin{array}{l}-0.125^{*} \\
(0.054)\end{array}$ & & & $\begin{array}{c}0.000 \\
(0.006)\end{array}$ \\
\hline Percent Declared Retired & \multicolumn{3}{|c|}{0.107} & \multicolumn{3}{|c|}{0.365} & \multicolumn{3}{|c|}{0.640} & \multicolumn{3}{|c|}{0.927} \\
\hline Pseudo R-squared & 0.015 & 0.293 & 0.293 & 0.015 & 0.231 & 0.231 & 0.038 & 0.174 & 0.178 & 0.020 & 0.310 & 0.310 \\
\hline Observations & 5,470 & 5,470 & 5,470 & 2,182 & 2,182 & 2,182 & 1,657 & 1,657 & 1,657 & 4,700 & 4,700 & 4,700 \\
\hline
\end{tabular}

Note: Robust standard errors in parentheses that allow for clustering for at the disaggregate country level which includes accounting for clustering of individuals across time. $* * \mathrm{p}<0.01, * \mathrm{p}<0.05,+\mathrm{p}<0.1$. All regressions include year, region and remoteness dummies. The second and third specifications also include controls for individual and househoold characteristics as shown in Table 2. 
Appendix Table 4: Probit Model of Likelihood of Being Retired by Age-Group - The Importance of Citizenship (Marginal Effects and Standard Errors)

\begin{tabular}{|c|c|c|c|c|c|c|c|c|c|c|}
\hline & \multicolumn{5}{|c|}{ Men } & \multicolumn{5}{|c|}{ Women } \\
\hline & Overall & Age $<60$ & Age 60-64 & Age $65-69$ & Age $>69$ & Overall & Age $<55$ & Age 55-59 & Age 60-64 & Age $>64$ \\
\hline \multicolumn{11}{|c|}{ Main Specification - Sample Resticted to Individuals with Citizenship Variables } \\
\hline \multirow[t]{2}{*}{ Log Emigration Rate } & $-0.094 * *$ & $-0.029 * *$ & -0.033 & $-0.158 * *$ & -0.003 & -0.005 & 0.004 & 0.012 & -0.018 & -0.002 \\
\hline & $(0.032)$ & $(0.011)$ & $(0.051)$ & $(0.051)$ & $(0.011)$ & $(0.045)$ & $(0.014)$ & $(0.082)$ & $(0.042)$ & $(0.006)$ \\
\hline Pseudo R-squared & 0.578 & 0.405 & 0.278 & 0.338 & 0.344 & 0.549 & 0.302 & 0.221 & 0.175 & 0.308 \\
\hline Observations & 12,720 & 6,938 & 1,657 & 1,331 & 2,794 & 13,453 & 5,226 & 2,101 & 1,602 & 4,496 \\
\hline \multicolumn{11}{|c|}{ Main Specification - Citizenship Variables Replace Immigrant Status Variables } \\
\hline \multirow[t]{2}{*}{ Log Emigration Rate } & $-0.106^{* *}$ & $-0.041 * *$ & $-0.086^{*}$ & -0.077 & -0.003 & -0.010 & 0.005 & 0.006 & $-0.069+$ & -0.001 \\
\hline & $(0.023)$ & $(0.013)$ & $(0.041)$ & $(0.064)$ & $(0.012)$ & $(0.038)$ & $(0.010)$ & $(0.068)$ & $(0.037)$ & $(0.007)$ \\
\hline \multirow[t]{2}{*}{ Not Citizen * CoB No Dual } & $0.295^{*}$ & 0.233 & 0.211 & 0.079 & All & 0.195 & 0.025 & 0.077 & $0.195 * *$ & All \\
\hline & $(0.122)$ & $(0.143)$ & $(0.148)$ & $(0.067)$ & Retired & $(0.129)$ & $(0.090)$ & $(0.095)$ & $(0.064)$ & Retired \\
\hline \multirow[t]{2}{*}{ Citizen * CoB No Dual Allowed } & 0.047 & 0.015 & -0.033 & $0.117 * *$ & 0.012 & 0.065 & -0.008 & 0.025 & All & 0.005 \\
\hline & $(0.049)$ & $(0.024)$ & $(0.086)$ & $(0.025)$ & $(0.014)$ & $(0.057)$ & $(0.018)$ & $(0.072)$ & Retired & $(0.015)$ \\
\hline \multirow[t]{2}{*}{ Not Citizen $*$ CoB Allows Dual } & $0.119 * *$ & 0.067 & 0.057 & $0.161 * *$ & -0.012 & $0.107+$ & 0.003 & 0.024 & $0.191 * *$ & $0.015 * *$ \\
\hline & $(0.031)$ & $(0.046)$ & $(0.065)$ & $(0.021)$ & $(0.020)$ & $(0.060)$ & $(0.026)$ & $(0.082)$ & $(0.047)$ & $(0.005)$ \\
\hline \multirow[t]{2}{*}{ Citizen $*$ CoB Allows Dual } & $0.103^{* *}$ & 0.028 & $0.139 *$ & $0.126^{*}$ & 0.010 & $0.099 *$ & -0.003 & 0.031 & $0.234 * *$ & $0.013 *$ \\
\hline & $(0.027)$ & $(0.022)$ & $(0.055)$ & $(0.050)$ & $(0.011)$ & $(0.040)$ & $(0.013)$ & $(0.085)$ & $(0.036)$ & $(0.006)$ \\
\hline Pseudo R-squared & 0.579 & 0.408 & 0.281 & 0.331 & 0.345 & 0.549 & 0.302 & 0.221 & 0.166 & 0.309 \\
\hline Observations & 12,720 & 6,938 & 1,657 & 1,331 & 2,780 & 13,453 & 5,226 & 2,101 & 1,561 & 4,510 \\
\hline
\end{tabular}

Note: Robust standard errors in parentheses that allow for clustering for at the disaggregate country level which includes accounting for clustering of individuals across time. $* * \mathrm{p}<0.01, * \mathrm{p}<0.05,+\mathrm{p}<0.1$. All regressions include controls for individual and househoold characteristics as shown in Table 2 and year, region and remoteness dummies.. 